\title{
Research progress on dendritic cell vaccines in cancer immunotherapy
}

\author{
Jifeng $\mathrm{Yu}^{1,2+}{ }^{1}, \mathrm{Hao}$ Sun ${ }^{1 \dagger}{ }^{1}$, Weijie Cao ${ }^{1}$, Yongping Song ${ }^{3 *}$ and Zhongxing Jiang ${ }^{1 *}$
}

\begin{abstract}
Dendritic cell (DC) vaccines induce specific immune responses that can selectively eliminate target cells. In recent years, many studies have been conducted to explore DC vaccination in the treatment of hematological malignancies, including acute myeloid leukemia and myelodysplastic syndromes, as well as other nonleukemia malignancies. There are at least two different strategies that use DCs to promote antitumor immunity: in situ vaccination and canonical vaccination. Monocyte-derived DCs (mo-DCs) and leukemia-derived DCs (DCleu) are the main types of DCs used in vaccines for AML and MDS thus far. Different cancer-related molecules such as peptides, recombinant proteins, apoptotic leukemic cells, whole tumor cells or lysates and DCs/DCleu containing a vaster antigenic repertoire with RNA electroporation, have been used as antigen sources to load DCs. To enhance DC vaccine efficacy, new strategies, such as combination with conventional chemotherapy, monospecific/bispecific antibodies and immune checkpointtargeting therapies, have been explored. After a decade of trials and tribulations, much progress has been made and much promise has emerged in the field. In this review we summarize the recent advances in DC vaccine immunotherapy for AML/MDS as well as other nonleukemia malignancies.
\end{abstract}

Keywords: Dendritic cell vaccine, Acute myeloid leukemia, Myelodysplastic syndrome, Cancer immunotherapy

\section{Introduction}

Acute myeloid leukemia (AML) and myelodysplastic syndrome (MDS) are common hematopoietic diseases characterized by uncontrolled clonal malignant cell proliferation with leukemic blasts replacing the cells that perform normal physiological hematopoiesis and associated symptoms of anemia, bleeding, and infections [1-3]. High-dose induction chemotherapies, followed by allogeneic hematopoietic stem cell transplantation (HSCT), are the only curative options in selected patients $[1,4$, $5]$. With advances in combined treatment options, the majority of patients can achieve remission after induction

\footnotetext{
*Correspondence: Songyongping001@126.com; jiangzx@zzu.edu.cn

${ }^{\dagger}$ Jifeng Yu and Hao Sun contributed equally to this work

${ }^{1}$ The First Affiliated Hospital of Zhengzhou University,

Zhengzhou 450052, Henan, China

${ }^{3}$ Department of Hematology, The Affiliated Cancer Hospital

of Zhengzhou University and Henan Cancer Hospital, Zhengzhou 450008, Henan, China

Full list of author information is available at the end of the article
}

chemotherapy; however, only a minority of patients enjoy durable responses. Drug resistance and relapse remain the major challenges, and the 5 -year overall survival (OS) rate of AML patients has stagnated at less than $30 \%[1,6$, 7].

It is well established that the curative effect of allogeneic HSCT derives from allogeneic lymphocyte-mediated graft versus leukemia (GVL) reactivity $[8,9]$. However, the complexity, cost and high rates of HSCT related morbidity and mortality have limited the clinical application of HSCT in all patients. Alternative curative approaches to harness antileukemia immunity have been under active investigation in recent decades. Dendritic cell (DC) vaccination as immunotherapy in patients with AML was initiated a few years after DCs were discovered by Ralph Steinman in 1973 [10] but did not see much progress for a long time. Recently, DC vaccination in AML and MDS has received renewed attention with new technologies applied in the vaccine development and patient selections $[11,12]$. Different types of DC vaccination strategies original author(s) and the source, provide a link to the Creative Commons licence, and indicate if changes were made. The images or other third party material in this article are included in the article's Creative Commons licence, unless indicated otherwise in a credit line to the material. If material is not included in the article's Creative Commons licence and your intended use is not permitted by statutory regulation or exceeds the permitted use, you will need to obtain permission directly from the copyright holder. To view a copy of this licence, visit http://creativecommons.org/licenses/by/4.0/. The Creative Commons Public Domain Dedication waiver (http://creativeco mmons.org/publicdomain/zero/1.0/) applies to the data made available in this article, unless otherwise stated in a credit line to the data. 
using a variety of antigen sources to promote antitumor immunity have been explored. Recently, DC vaccines combined with conventional chemotherapy, systemic monoclonal antibodies or immune checkpoint-targeting strategies, such as those targeting programmed death $1 /$ programmed death-ligand 1 (PD-1/PD-L1), have been studied. Although the development of DC vaccination in patients with AML and MDS has progressed somewhat, there is still a long way to go before therapeutic DC vaccines can be translated from the research laboratory to the bedside. In this review, we summarize the recent advances in DC vaccines immunotherapy for AML/MDS as well as other nonleukemia malignancies.

\section{DC vaccine cell types and clinical data}

DCs are major antigen presenting cells (APCs) that process and present antigens via major histocompatibility complex I and II (MHC I and II) molecules to the innate and adaptive immune systems [13] and play a key role in the interface and crosstalk of the innate and adaptive immune systems [14]. DCs activate NK cells to control pathogens through the innate immune system and activate the adaptive immune system to realize immune memory [15]. Furthermore, DCs form immunological synapses with $\mathrm{T}$ cells, resulting in potent $\mathrm{T}$-cell activation against the presented antigens [16]. DCs can enable $\mathrm{CD}^{+} \mathrm{T}$ cells to activate $\mathrm{B}$ and $\mathrm{CD} 8^{+} \mathrm{T}$ cells, mediate immune memory, and activate Tregs to exert important immunosuppressive functions [17]. Based on developmental, phenotypical and functional criteria, different DC subpopulations have been identified, such as conventional DCs (cDCs), plasmacytoid DCs (pDCs), and monocyte-derived DCs (Mo-DCs) [13]. Based on the automated identification of DCs through unsupervised analysis of conventional flow cytometry and mass cytometry data obtained from multiple species, DCs have been categorized into different classes, and their characteristics and functions have been reported by different groups, as summarized in Table 1 [13, 17-19]. Different types of $\mathrm{DC}$ vaccines have been developed in the past years. The major types of DCs used in DC vaccines include Mo-DCs and leukemia-derived DCs (DCleu), which can be modified with different methods. A depiction of DC vaccine preparation procedures and technological advances in hematological malignancy research are summarized in Fig. 1.

\section{Clinical data from monocyte-derived DC vaccines}

Mo-DCs are an important DC source for DC vaccinations and can be generated ex vivo from autologous or allogeneic CD14 $4^{+}$monocytes [20]. Mo-DCs can be loaded with leukemia-associated antigens (LAAs) [21]. Antigens such as Wilms' tumor 1 (WT1), preferentially expressed antigen of melanoma (PRAME), and human telomerase reverse transcriptase (hTERT) have been used as LAAs for Mo-DC loading [20, 22]. Mo-DCs can also be loaded with whole apoptotic leukemic cells, leukemia cell lysates or leukemic cell-derived RNA/mRNA [20, 23, 24]. These Mo-DCs can be readministered to AML patients in intradermal or intravenous DC vaccination [20, 22]. A recent feasibility study demonstrated that using cryopreservation of Mo-DCs can be a good method to preserve the cells before use in immunotherapy, avoiding variability within the same individual due to several blood draws [25].

Clinical trials using Mo-DC vaccines for the treatment of AML have demonstrated various successes [20, 24]. In a clinical study, cross-priming of $\mathrm{CD} 8^{+} \mathrm{T}$ cells in vivo by DCs pulsed with autologous apoptotic leukemic cells was used as immunotherapy for elderly patients with acute myeloid leukemia. Antileukemic responses were observed in two of the four study patients with longer periods of disease stabilization [62]. Similarly, vaccinations using Mo-DCs pulsed with leukemic lysates from AML patients who had relapsed after autologous HSCT induced immunological responses and increased autologous $\mathrm{T}$ cell ability to stimulate DCs, indicating that MoDCs are a feasible cellular therapy for relapsing AML after autologous HSCT [20, 24, 26]. However, more clinical studies are needed to further define the efficacy of Mo-DC vaccines in AML and MDS.

\section{Clinical data from leukemia-derived $D C$ vaccines}

In AML and MDS, DCs can be generated directly from DCleu after culture with different combinations of modifiers [27-29]. Different DCleu-generating protocols have been developed [30]. The morphology of DCleu is similar to that of typical DCs. DCleus have stronger antigen presentation capability, stronger ex vivo antileukemia immune response and enhanced costimulatory molecule expression [12]. The ex vivo production of Mo-DCs and generation of DCleu from leukemic blood cells for vaccinations are challenging processes. However, production protocols have been improved and streamlined [30]. Analysis of these DCleu demonstrated the expression of various specific whole leukemic antigens from patients [31, 32]. The confirmation methods of DCleu include Western blot, immunophenotyping and fluorescence in situ hybridization (FISH) with chromosome-specific DNA probes to detect leukemia-specific numeric or structural chromosomal aberrations in the generated DCleu [33, 34]. Additionally, a special flow cytometric gating strategy has been developed. Using patient-specific blast-staining antibodies together with some unique DCstaining antibodies, some unique antigens that are not expressed on leukemic blasts before DCleu generation 


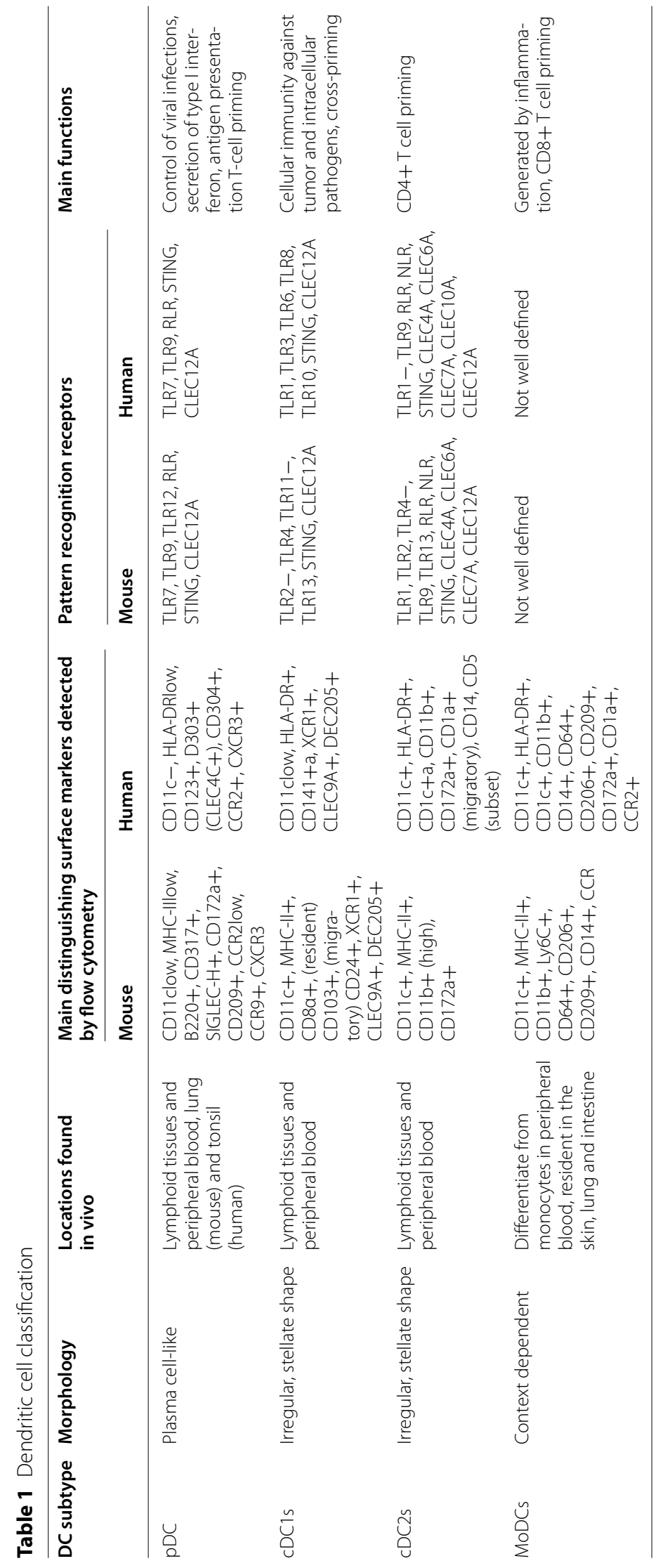




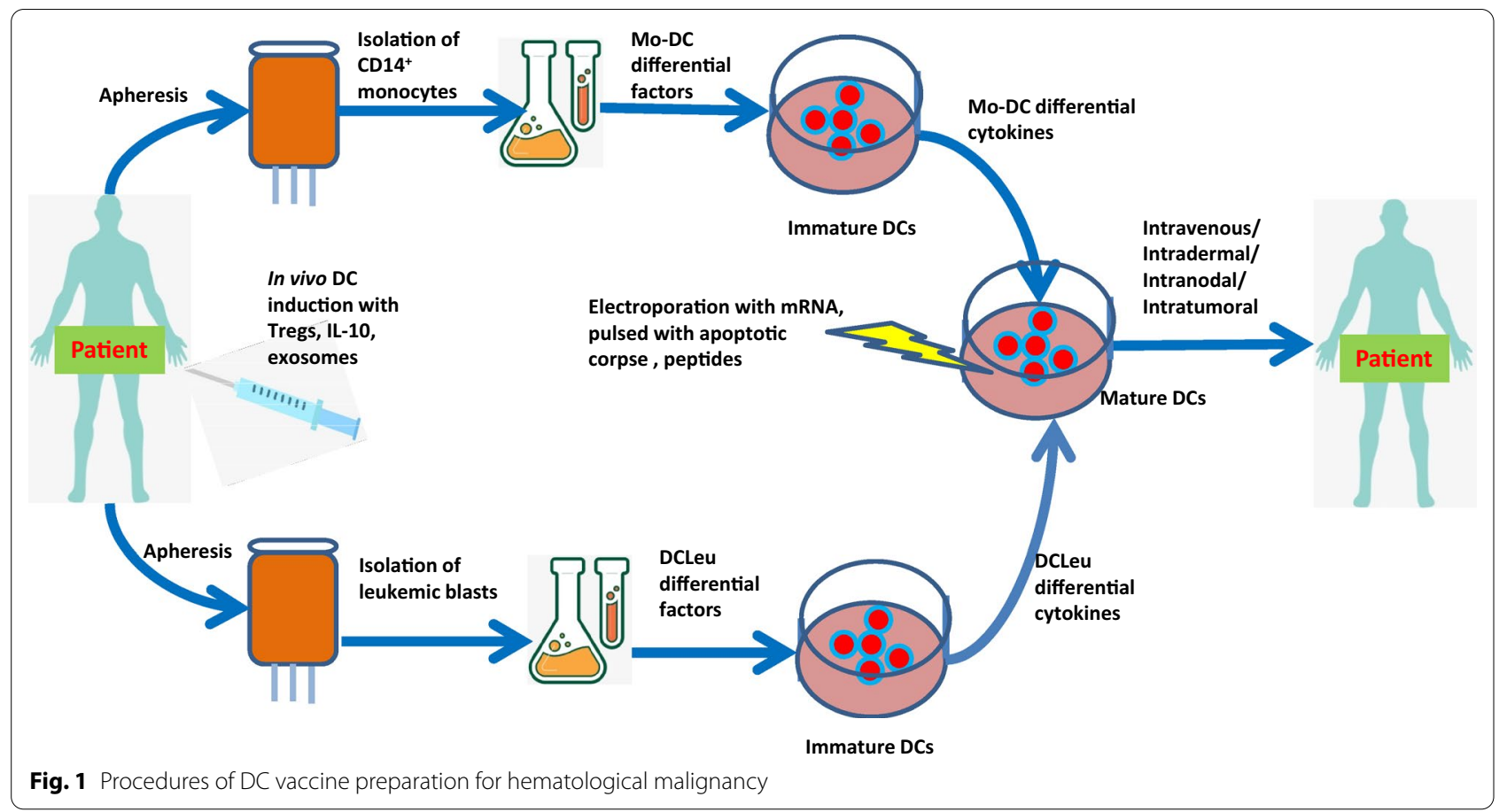

can be detected [34, 35]. After blast/DC populations are cultured in DC-generating media, the blast/DC population can be further divided into different subpopulations, such as leukemia-derived DCs, nonleukemia-derived DCs and nonconverted blasts [34]. It has been demonstrated that only mature DCleu can activate immune reactive cells. These mature DCleu express chemokine receptor 7 (CCR7), which is crucial for the migratory capacity of DCleu [12, 36]. Furthermore, mature DCleu also expresses CD83 and secrete IL-12 [37].

Both myeloid leukemia cells and DCs are derived from myeloid progenitor cells, but they have completely different characteristics and $T$ cell stimulation functions. The majority of leukemia cells do not express CD80, only express low levels of CD86 [38,39] and have poor $\mathrm{T}$ cell stimulatory capacity or even induce $\mathrm{T}$ cell anergy $[40,41]$. Myeloid leukemia cells can be induced to differentiate into DCleu [42] by using various stimulants, such as GM-CSF plus IL- 4 with either TNF- $\alpha$ or CD40 ligand (CD40L) [43]. CD40L can induce immature DCleu to become fully mature DCleu and produce stronger $\mathrm{T}$ cell stimulation capability [44]. Mature DCleu can gain potent migratory capacity after culture with a group of cytokines [45]. Preliminary reports of clinical trials using AML-DC vaccination in AML patients in the palliative setting have shown therapeutic efficacy $[46,47]$.

Different loading strategies including loading DCs with select leukemia-derived antigenic peptides [12, 13, 4850], pulsing DCs with whole leukemia apoptotic bodies
$[12,13,42,48,51]$, pulsing DCs with leukemia lysates [12, $13,48,51]$, and transfecting DCs with mRNA derived from leukemic cells [12, 13, 48, 52], have been explored by different groups. The advantages and disadvantages of these loading strategies are summarized in Table 2.

The strategy using genetically modified whole leukemia cells to express costimulatory ligands and/or immunostimulatory cytokines as vaccines has attracted much interest [42]. Genetically modification of leukemia cells to express costimulatory molecules such as CD80 has been successfully applied for almost all leukemia patient samples regardless of the type of leukemia [42]. Preclinical in vitro studies have demonstrated that CD80 transduction enhances the T-cell stimulatory capacity [53] and the immunogenicity of leukemia cells $[54,55]$.

It has been demonstrated that DCleu increase T-cell activation and shift $\mathrm{T}$ cell subsets to a higher activation status in a mixed-lymphocyte culture (MLC), with increased functional $\mathrm{T}$ cells and decreased regulatory cells $[56,57]$. These findings validate that ex vivo generated DCleu can help to overcome anergy of immune reactive cells in AML and prime effector T cells to exert antileukemic effects against different antigens [31]. In addition, ex vivo-generated DCleu from AML and MDS patients can be used as a predictive factor for the cytolytic potential of leukemia-specific functional $\mathrm{T}$ cells induced by DCs. DCleu stimulation can induce specific antileukemic activity against leukemic blasts after MLC [58]. 
Table 2 Dendritic cell vaccine loading strategies

\begin{tabular}{|c|c|c|c|}
\hline DC vaccine loading strategies & Advantages & Disadvantages & Main references \\
\hline $\begin{array}{l}\text { Loading DCs with leukemia-derived anti- } \\
\text { genic peptides }\end{array}$ & $\begin{array}{l}\text { Long-term effect of DC vaccine } \\
\text { Broader tumor antigens for desired DC- } \\
\text { based vaccines } \\
\text { Powerful ability to elicit antigen specific } T \\
\text { cell functions } \\
\text { Targeting of different epitopes through } \\
\text { different DC sources and/or routes of } \\
\text { administration }\end{array}$ & $\begin{array}{l}\text { Tumor antigens or HLA molecule expres- } \\
\text { sion or both may be lost in the course of } \\
\text { disease } \\
\text { Tolerance increases due to the expression } \\
\text { of shared antigens by normal cells }\end{array}$ & {$[12,13,48-50]$} \\
\hline $\begin{array}{l}\text { Pulsing DCs with whole leukemia apop- } \\
\text { totic bodies }\end{array}$ & $\begin{array}{l}\text { Contains both known and unknown } \\
\text { immunogenic antigens } \\
\text { Canbe loaded with costimulatory and } \\
\text { adhesion molecules } \\
\text { Can activate both the innate and adaptive } \\
\text { immune systems to induce tumor-specific } \\
\text { CD4 and CD8 T cells }\end{array}$ & $\begin{array}{l}\text { Autoimmunity and/or immunotolerance } \\
\text { can be the rare potential issues due to } \\
\text { LAAs shared by normal hematopoietic } \\
\text { cells }\end{array}$ & {$[12,13,42,48,51]$} \\
\hline Pulsing DCs with leukemia cell lysates & $\begin{array}{l}\text { Better than apoptotic body vaccines } \\
\text { A wider array of antigenic epitopes to } \\
\text { stimulate a larger proportion of the CTL } \\
\text { repertoire } \\
\text { May have interaction of DCs and NK cells }\end{array}$ & $\begin{array}{l}\text { Lower capacity to elicit a broad spectrum } \\
\text { of CTLs than apoptotic cells } \\
\text { Potential cytotoxicities } \\
\text { Longer processing and purification proce- } \\
\text { dures than whole leukemic cell vaccines } \\
\text { and mRNA vaccines }\end{array}$ & {$[12,13,48,51]$} \\
\hline $\begin{array}{l}\text { Transfecting DCs with mRNA derived from } \\
\text { leukemic cells }\end{array}$ & $\begin{array}{l}\text { Higher transduction efficiency; strong } \\
\text { T-cell stimulatory effect } \\
\text { Relatively longer mRNA antigen expres- } \\
\text { sion time } \\
\text { Various leukemic antigens can be } \\
\text { included with the total mRNA } \\
\text { Amplified total tumor m-RNA can obtain } \\
\text { unlimited amount of tumor antigens } \\
\text { without the need for the search of specific } \\
\text { tumor antigens in each patient }\end{array}$ & $\begin{array}{l}\text { Passive m-RNA loading with weaker stimu- } \\
\text { latory capacity than m-RNA transfection } \\
\text { Safety and vector immunogenicity issues } \\
\text { with the viral vectors }\end{array}$ & {$[12,13,48,52]$} \\
\hline
\end{tabular}

Ex vivo-manufactured DCleu can be readministered to patients as a subcutaneous vaccine after irradiation to avoid transfer of leukemic blasts [34]. Promising results have been reported from several clinical trials with autologous DCleu [46, 47, 59]. Overall, vaccinations with DCleu have been well tolerated, and only a few adverse effects such as extensive eczema, were found in a minority of patients, possibly due to autoimmunity induction $[46,47,59]$. In one leukemia DC vaccine trial, five AML patients received up to four administrations at a biweekly interval without severe adverse side effects. Three of the five patients completed the treatment with four AML-DC vaccinations and remained in a stable condition for 5.5-13 months while the other two patients died from rapidly progressive AML [47]. In a separate trial, five patients received an escalating dose of DCleu once a week after achieving $\mathrm{CR}$ from intensive chemotherapy. It was demonstrated that cytotoxic $\mathrm{T}$ lymphocytes (CTLs) with IFN- $\gamma$ secreting antileukemic activities increased and that WT1-specific CTLs could be detected [46]. After vaccination, specific $\mathrm{CD}^{+} \mathrm{T}$ cells and a higher intracellular IFN- $\gamma$ concentration in $\mathrm{CD} 4^{+}$cells were detected [47].
To further improve DC vaccine efficacy, vaccination with both autologous DCs and ex vivo-generated autologous cytokine-induced killer cells $\left(\mathrm{CD}^{+} \mathrm{CD} 56^{+}\right.$cells) has also been studied [59]. Compared to patients treated with low-dose chemotherapy alone, patients treated with DCleu vaccination achieved significantly higher complete remission (CR) and partial remission (PR) rates [59].

As mentioned previously, the graft versus leukemia effect is the mechanism underlying the leukemia cure induced by allogeneic HSCT, and the allogeneic DCleu vaccine has attracted researchers' interest. Using an AML cell line expressing a wide range of LAAs, an allogeneic DCleu vaccine was developed for a phase I clinical trial as a post-HSCT therapy in 12 elderly AML patients. In vivo cellular and humoral immunities were observed with few adverse effects [60]. Patients with no circulating blasts showed unusually prolonged survival whereas patients with circulating blasts died within 6 months. Long-term survival was correlated with maintained $\mathrm{T}$ cell levels and induction of multifunctional immune responses [60].

In a phase I/II vaccination clinical trial using a personalized DCleu vaccine with patient-derived AML cells fused with autologous dendritic cells, among the 17 
participating AML patients, 12 demonstrated durable expansion of leukemia-specific T cells. Despite a median age of 63 years, $71 \%$ of patients remained alive without disease recurrence at a median follow-up of 57 months, demonstrating that this personalized vaccine induces anti-AML cell immunity and provides protection against disease relapse [61]. Currently, on the clinicaltrials.gov website, eight ongoing clinical trials employing either allogeneic DC or autologous DC and different vaccination methods for the treatment of patients with AML and MDS are listed up as of the end of November 2021 (Table 3).

An ex vivo culture system for AML patients simulating physiological conditions has been established using a combination of at least 2 cytokines or response modifiers ("Kits") to induce DC/DCleu generation [12, 27]. One of the key agents in the "Kits" is IL-15 [62]. In contrast to the conventional IL-4 Mo-DCs used in vaccines, IL15-differentiated DCs have superior antigen-presenting capability and direct antitumor activity via the expression of IL-15 [63] and make use of both NK cells and $\gamma \delta$ $\mathrm{T}$ cells in the antitumor immune response $[64,65]$. Significantly higher amounts of $\mathrm{T}$ effector or $\mathrm{T}$ memory cells are found in MLC with Kit-generated DC/DCleu [27, 66]. The clinical application of ex vivo generation of DCs/ DCleu may be a reality soon, since all Kit components have been approved for human treatment individually in the clinical setting; for example, GM-CSF is used for neutropenia in patients after chemotherapy or HSCT [67].

\section{Clinical data from in vivo induced DC vaccines}

Different regulatory mechanisms of in vivo-induced DCs against leukemic cells have been proposed, i.e., regulatory $\mathrm{T}$ cells (Tregs), regulatory cytokines (e.g., IL-10) and exosomes [56, 57, 68, 69] (Figs. 2, 3). Exosomes for DC pulsing have demonstrated clinical efficacy in preliminary experiments [70,71]. Recently, the results of a phase I/II vaccine feasibility study of autologous leukemic apoptotic corpse-pulsed DCs for elderly AML patients in the first or second CR with the pulsed DC administered at doses of $9 \times 10^{6}$ subcutaneously $(1 \mathrm{~mL})$ and $1 \times 10^{6}$ intradermally $(0.1 \mathrm{~mL})$ were reported. Five doses of vaccine were applied on days $+1,+7,+14,+21$, and +35 . No severe adverse events were observed after five DC vaccines were produced for and injected into all five patients in the study [72]. The extended phase II study to delineate the roles of $\mathrm{DC}$-vaccines in AML populations is ongoing under the clinical trial \# NCT01146262.

\section{Strategies for anti-leukemia vaccination}

There are at least two different strategies involving DCs that can be used to promote antitumor immunity: in situ vaccination and canonical vaccination. The in situ approach relies on the release of tumor antigens locally through standard therapies to promote DC antigen uptake and tumor immune recognition, whereas the canonical approach relies on the loading of tumor antigens into DCs in vitro before delivering DCs to patients [11]. In recent years, different novel methods for DC vaccine production have been developed, such as immunogenic cell death induction, mRNA transfection, and delivery of peptides to DCs in vivo via cell penetrating peptides [73].

Antigen source selection is crucial in DC vaccination. Previously validated molecules such as peptides, recombinant proteins, whole tumor cells or lysates have been used as antigens in therapeutic vaccine development, although some tumor cell variants may lose antigens through the immune editing process [74]. Either irradiated whole tumor cells or apoptotic whole tumor cells have been used [75]. Whole leukemia cell vaccines can induce immune responses against multiple unknown antigens. However, peptide vaccines elicit immune response against only specific epitopes [76]. The other strategy to generate a whole leukemia cell vaccine is to genetically modify leukemia cells to express costimulatory ligands such as CD80 [76].

Strategies to design AML vaccines include administration of Wilms' tumor 1 (WT1) peptide with adjuvant [77, 78], DCs with WT1 tumor antigens $[79,80]$, or DCleu [56]. A systematic review of 9 clinical trials of WT1 peptide vaccines for MDS/AML patients demonstrated that the WT1 peptide vaccine was safe and feasible. Clinical responses and benefits were observed, as some patients achieved and maintained remission for more than 8 years [17]. Mature DCs loaded with RNA encoding WT1 can stimulate an AML-specific $\mathrm{T}$ cell-based immune response. Both in vitro and in vivo studies have demonstrated that DCs enhance the induction of tumor-specific immune responses [18]. Clinical trial results show that DC/AML fusion vaccines are well tolerated and yield much less toxicity than other methods; for example, pneumonitis is induced with immune checkpoint inhibitors and cytokine release syndrome is induced with the infusion of activated T cells [81-83]. Significant clinical improvement has been observed with a reduction in peripheral blasts in many patients, with the longest survival being more than 3 years [80, 84-86]. Expansion of the leukemia-specific $\mathrm{T}$ cells recognizing WT1, MUC1 and other antigens can enhance immune response specificity. Since MUC1 is only expressed by leukemic stem cells, it has become a unique potential target for this selfrenewing population [87]. Numerous studies have demonstrated that $\mathrm{DC}$ vaccines can reverse $\mathrm{T}$ cell exhaustion and restore $\mathrm{T}$ cell function. A preclinical study has demonstrated that targeting the PD- 1 and Tim-3 pathways 


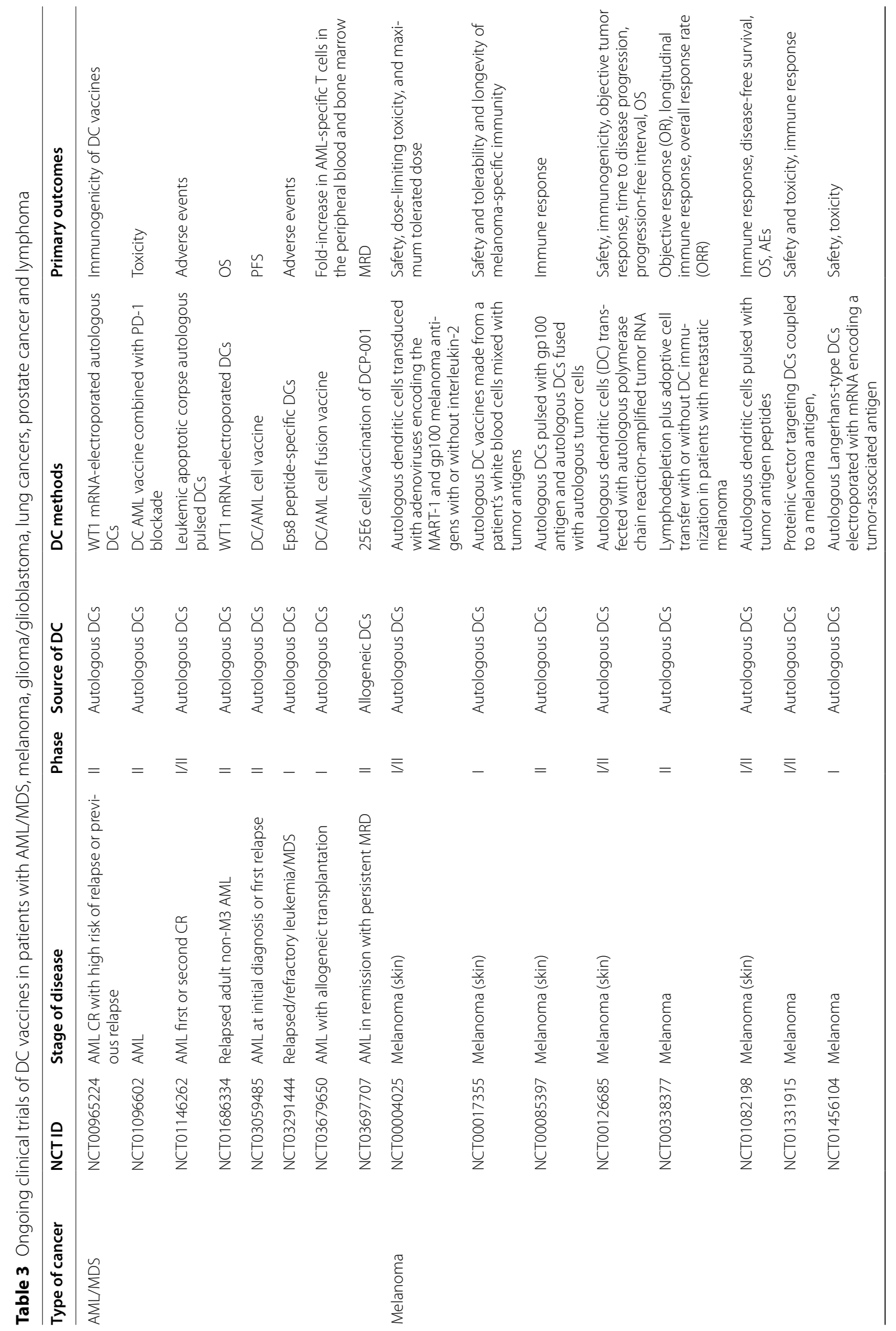




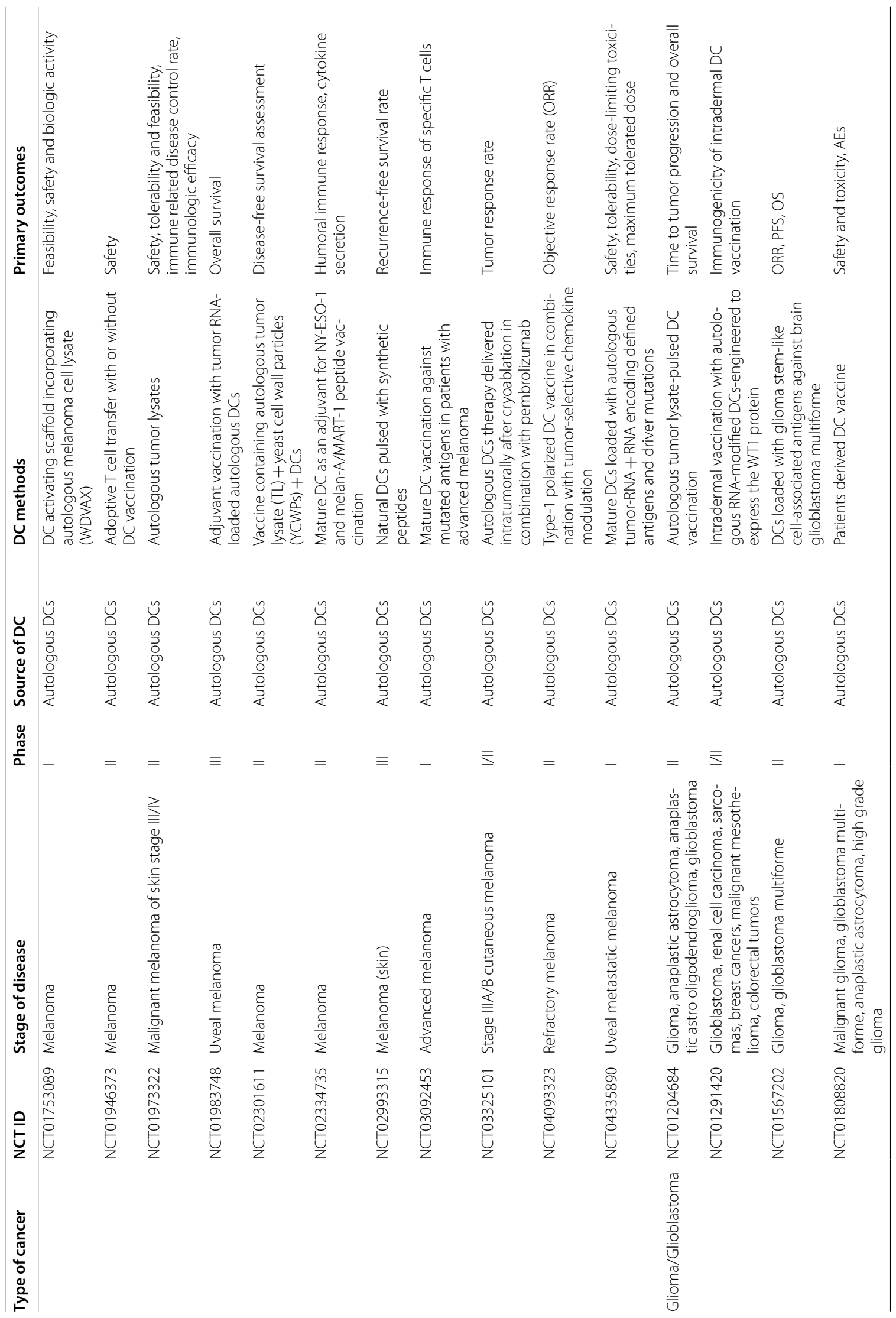




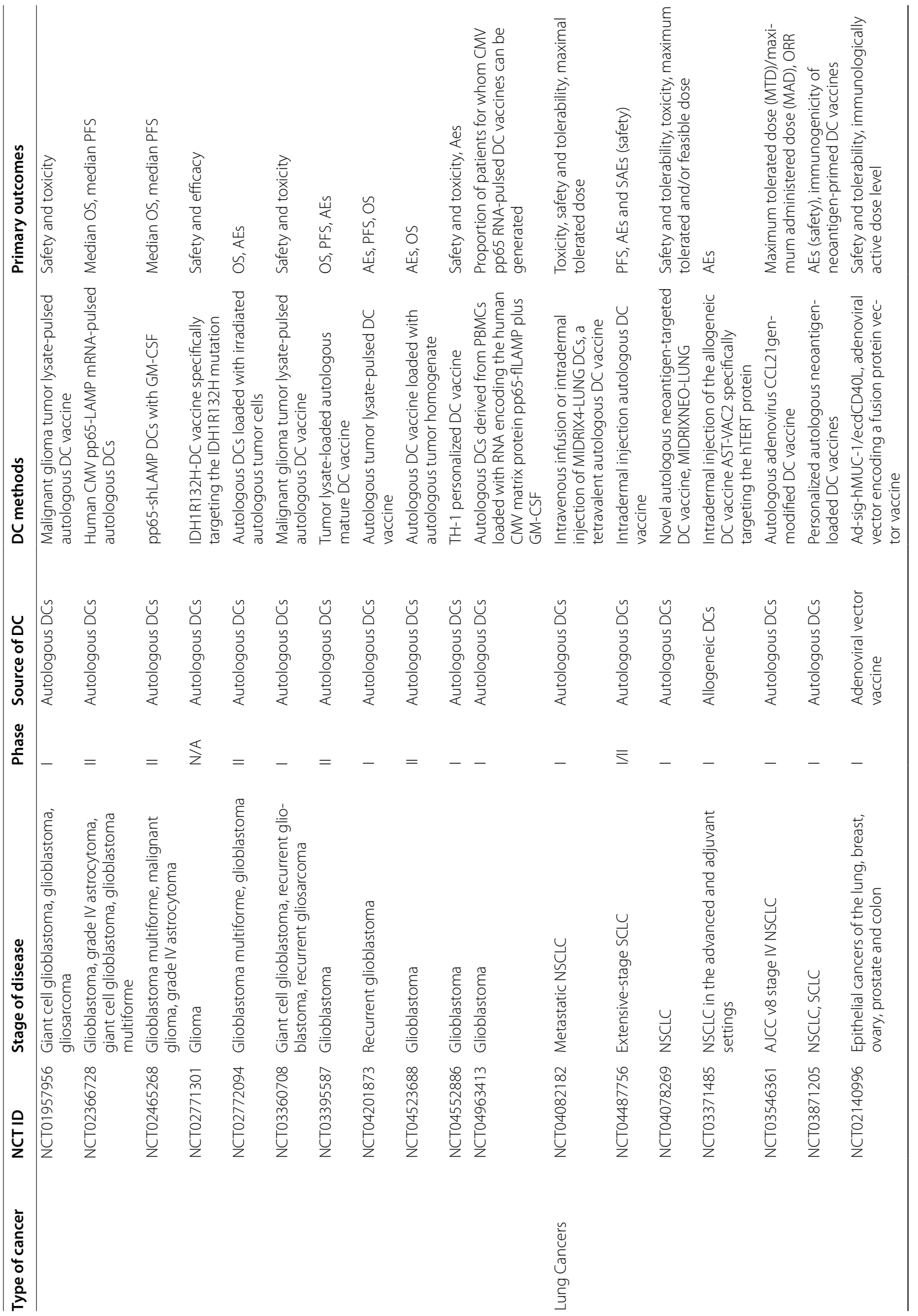




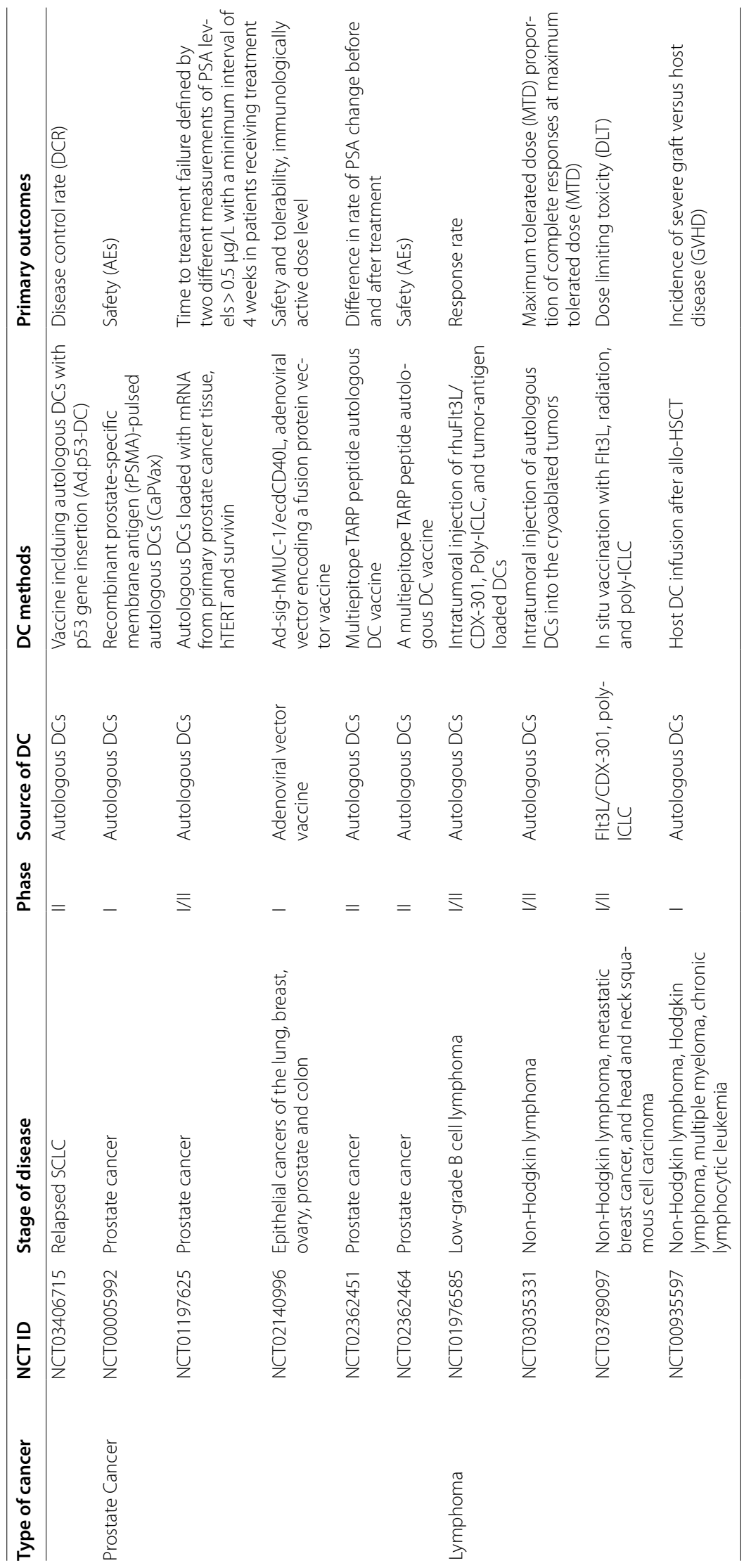


can reverse CD8 $\mathrm{T}$ cell exhaustion and enhance ex vivo $\mathrm{T}$ cell responses to autologous dendritic/tumor cell vaccines [88]. Furthermore, leukemia derived vaccine can overcome the limitations of checkpoint blockade by evoking clonal $\mathrm{T}$ cell responses in a murine AML model. Vaccination with DC/AML fusions resulted in the expansion of tumor-specific lymphocytes and disease eradication in a subset of animals, while the combination of vaccination and checkpoint blockade induced a fully protective tumor-specific immune response in all treated animals. Vaccination followed by checkpoint blockade resulted in upregulation of genes regulating activation and proliferation in memory and effector $\mathrm{T}$ cells. Longterm survivors exhibited increased $\mathrm{T}$ cell clonal diversity and were resistant to subsequent tumor challenge [89]. A phase I/II clinical trial demonstrated that autologous DCs in combination with chemotherapy can restore the responsiveness of $\mathrm{T}$ cells in breast cancer patients [90].

Recently, human $\gamma \delta \mathrm{T}$ cells have attracted attention in DC vaccine research. Human $\gamma \delta$ T cells are heterogeneous subsets of unconventional lymphocytes with human leukocyte antigen (HLA)-unrestricted target cell recognition. Several studies have demonstrated that the crosstalk of $\gamma \delta$ T lymphocytes with DCs plays a crucial role in the orchestration of the immune response by bridging innate and adaptive immunity. Studies using a combination of DC-based vaccines with $\gamma \delta \mathrm{T}$ cells demonstrated strong synergy, long-term tumor control and protection against escaping tumor clones [91].

In WT1 mRNA-electroporated DC vaccination clinical trials in AML patients, the OS rates and the WT1-specific $\mathrm{CD}^{+} \mathrm{T}$ cell response were improved significantly [92]. In 30 AML patients with a very high risk of relapse, 13 patients demonstrated an obvious antileukemic response. Nine patients achieved molecular remission and 5 of them sustained this remission after a median follow-up of 109.4 months [92]. Furthermore, patients with different tumors including leukemia, brain tumors, prostate cancer, renal cell carcinoma, pancreatic cancer, as well as HIV infection have been treated with ex vivo-generated mRNA-transfected DCs [93]. In AML and chronic myeloid leukemia (CML) patients, both autologous and allogeneic DCs have been administered as cellular therapy [94]. However, the immunogenicity of leukemia cell vaccines can be limited by many factors [42], and new strategies are urgently needed to induce a potent antileukemic immune response.

\section{DC vaccines in nonleukemia malignancies Melanoma}

Melanoma is another malignant tumor in addition to AML and MDS in which DC vaccines have been widely studied. In the past few decades, great progress has been made in the clinical application of DC vaccines loaded with personalized neoantigens, which have been proven to be safe, immunogenic and feasible treatment strategies in patients with melanoma. With the increasing indepth understanding of DC biology, the next generation of highly efficient cancer vaccines may provide a new immunotherapy strategy for patients with melanoma [95]. Mo-DC vaccines loaded with tumor lysates can affect the tumor microenvironment (TME) and promote the transformation of a "cold" tumor into a "hot" tumor by inducing the activation and infiltration of $\mathrm{CD} 8^{+} \mathrm{T}$ lymphocytes and the upregulation of PD-L1 expression in patients with metastatic melanoma [96]. The combination of a DC vaccine with immune checkpoint inhibitors (ICIs) has been shown to be effective in treatment of melanoma patients. Even after recurrence in patients who received adjuvant DC vaccination, treatment with firstor second-line PD-1 inhibitor monotherapy resulted in a response rate of $52 \%$ [97]. A clinical study demonstrated complete and long-lasting clinical responses in patients with immune checkpoint inhibitor-resistant, metastatic melanoma treated with adoptive $\mathrm{T}$ cell transfer combined with $\mathrm{DC}$ vaccination, with clinical responses induced by tumor-infiltrating lymphocyte (TIL) therapy combined with DC vaccination seen in 4 out of 4 treated metastatic melanoma patients who previously failed ICI therapy [98]. Another study showed that although more patients showed a clinical response to TIL + DC therapy, the combination of TILs and DCs showed no difference in the persistence of MART-1 TILs compared with TIL therapy alone [99]. A study revealed that blockade of inducible costimulatory molecule ligand (ICOSL) on DCs reduced priming of antigen-specific $\mathrm{CD}^{+}$and $\mathrm{CD}^{+}{ }^{+} \mathrm{T}$ cells from naïve donors in vitro and that dysregulated NF-kBdependent ICOSL expression in human DC vaccines impaired $\mathrm{T}$ cell responses in patients with melanoma, which supports the implementation of targeted strategies to augment these pathways for improved immunotherapeutic outcomes in patients with cancer [100].

A phase II clinical trial of DC vaccines for patients with stage III/IV melanoma demonstrated improvement in patient survival over the course of a year. However, patients in the DC vaccine treatment group had a higher rate of early local regional relapse than those in the control group, and $80 \%$ of patients reported swelling and erythema at the site of intradermal DC-injection [101]. Another study showed that DC vaccines in combination with cisplatin in stage III and IV melanoma patients did not improve clinical outcomes compared to DC vaccination monotherapy [102].

More clinical trials are currently underway. As of the end of November 2021, there were 19 ongoing clinical trials with DC vaccines in patients with melanoma 
(Table 3). A DC vaccine with natural myeloid DCs loaded with synthetic peptides is currently in a clinical trial for the treatment of stage IIIB and IIIC melanoma patients (NCT02993315). In addition, a personalized vaccine including autologous DCs exposed to autologous whole tumor cell lysate in combination with the chemotherapy drug cyclophosphamide has been explored to treat advanced solid tumor patients with high tumor mutation burden in a phase I clinical trial (NCT03671720).

\section{Glioma/glioblastoma}

As the most frequent and aggressive malignant primary brain tumor, glioblastoma multiforme (GBM) has a highly fatal prognosis and disease recurrence is universal. There is no effective therapy for recurrent disease, and the median survival after relapse is 6.2 months [103]. Animal studies on glioblastoma have demonstrated that DC vaccines can reduce tumor growth, prolong survival, and induce tumor-specific IFN- $\gamma$ and cytotoxic T-lymphocyte (CTL) responses associated with T cell infiltration of tumors [103]. Numerous clinical trial studies have been initiated in GBM patients and have confirmed the feasibility and safety. Many of these studies reported induction of an antitumoral immune response and indicated improved survival after DC vaccine [104-108]. In a large phase III clinical trial of an autologous DC vaccine in newly diagnosed glioblastoma, the median OS was 23.1 months in patients who underwent surgery and DC vaccination, and vaccination-related grade 3 or 4 AEs were observed in only $2.1 \%$ of patients [104]. In another study of vaccination with DCs loaded with TAAs and/or mRNA of neoantigens in combination with low-dose cyclophosphamide in glioma patients, vaccination with DCs loaded with TAAs and the mRNA of neoantigens increased the life expectancy of patients. The median OS was 19 months and no grade 3 or higher AEs were observed [105]. A phase II clinical trial of alpha-type-1 polarized DCbased vaccination in newly diagnosed high-grade glioma revealed a significant survival-prolonging effect in DC-treated glioma patients. Ten of 15 evaluable patients showed positive CTL responses. After 6 years of observation, five patients were still alive, and two of these patients were relapse-free [106]. However, two publications of meta-analyses of randomized controlled studies on the efficacy of DC vaccines for newly diagnosed glioblastoma suggested that dendritic cell vaccines provide no obvious benefits for newly diagnosed glioblastoma [107, 108]. As of the end of November 2021, there were 15 ongoing clinical trials regarding DC vaccines in patients with glioma/glioblastoma (Table 3 ).

\section{Lung cancers}

Lung cancer is a common malignant tumor that threatens human life and is associated with high morbidity and mortality rates. Calreticulin (CALR) is a characteristic antigen involved in immunogenic cell death in nonsmall-cell lung cancer (NSCLC). A recent study showed that the CALR-TLR4 complex inhibits NSCLC progression by regulating the migration and maturation of DCs, providing a theoretical basis and ideas for immunotherapy of NSCLC [109]. In a pilot clinical trial study with a personalized neoantigen pulsed DC vaccine for advanced lung cancer (NCT02956551), the objective effectiveness rate was $25 \%$, the disease control rate was $75 \%$, the median progression-free survival (PFS) was 5.5 months, and the median OS was 7.9 months [110]. A randomizedcontrolled phase II trial of salvage chemotherapy after immunization with a TP53-transfected DC-based vaccine (Ad.p53-DC) in patients with recurrent small-cell lung cancer (SCLC) revealed that the vaccine was safe, with mostly grade $1 / 2$ toxicities and some grade 3 toxicities. The rate of positive immune responses were between 20 and $43.3 \%$ in different experimental arms. Although the vaccine failed to improve ORRs to second-line chemotherapy, its safety profile and therapeutic immune potential remain [111]. Small-scale manufacturing of neoantigen-encoding messenger RNA for early-phase clinical trials in lung cancer patients (NCT04078269) has been successfully applied for the clinical evaluation of MIDRIXNEO, a personalized mRNA-loaded dendritic cell vaccine targeting tumor neoantigens [112]. As of the end of November 2021, there were 8 ongoing clinical trials with DC vaccines in patients with lung cancers (Table 3).

Furthermore, a preclinical study on the effect of a DC vaccine loaded with tumor cell lysate (TCL-DCV) on the percentage of $\mathrm{CD} 166^{+}$cancer stem cells (CSCs) in the lungs of mice exposed to benzo(a)pyrene (BP) revealed that TCL-DCV reversed the tumorigenic effect of $\mathrm{BP}$ in the lungs. Compared to cisplatin, TCL-DCV significantly decreased the percentage of $\mathrm{CD}_{166}{ }^{+} \mathrm{CSCs}$, suggesting its potential as a cure for lung cancer [113]. A new PD-1-blocking nanobody (PD-1 Nb20) in combination with tumor-specific DC/tumor cell-fusions augments the broad spectrum of antitumor activity of $\mathrm{CD}^{+} \mathrm{T}$ cells, providing an alternative and promising immunotherapeutic strategy for tumor patients who have $\mathrm{T}$ cell-dysfunctional or no sensitivity to anti-PD-1 therapy [114].

\section{Prostate cancer}

Patients with high-risk prostate cancer can experience relapse and develop noncurative disease. Vaccines targeting TAAs or tumor-specific antigens have been applied in 
clinical trials as prostate cancer treatment. Different types of vaccines including DC-based (e.g., sipuleucel-T), peptide/protein-based, or gene-(DNA/RNA) based vaccines have been applied as adjuvant therapy in patients with prostate cancers [115]. Despite the initial success with sipuleucel-T, further $\mathrm{DC}$ vaccines have failed to progress. Emerging antigen loading and presentation technologies, such as nanoparticles, antibody-antigen conjugates and virus codelivery systems have been used to improve efficacy [116]. In a phase I trial of an antigen-targeted autologous DC-based vaccine with in vivo activation of inducible CD40 for advanced prostate cancer, immune upregulation and antitumor activity were observed, as were prostate-specific antigen decreases, objective tumor regression and robust efficacy of posttrial therapy [117]. Recently, a long-term first-in-human phase I/II study of an adjuvant DC vaccine in patients with high-risk prostate cancer after radical prostatectomy showed promising results. Among 12 patients with grade 5 prostate cancers, five achieved remission after 84 months, and all mounted immune responses [118]. As of the end of November 2021, there were 5 ongoing clinical trials with DC vaccines in patients with prostate cancers (Table 3).

\section{Lymphoma}

DC vaccine immunotherapy has been used in patients with lymphoma for a long time. The 15-year follow-up of relapsed indolent non-Hodgkin lymphoma patients vaccinated with tumor-loaded DCs demonstrated the absence of toxicity and benefit of active immunization. The results showed that the 5-year and 10-year PFS rates were $55.6 \%$ and $33.3 \%$, respectively; 10 -year OS rate was 83.3\%. Female patients experienced a better PFS and 22\% of patients experienced a long-lasting complete response. Different genes including KIT, ATG12, TNFRSF10C, PBK, ITGA2, GATA3, CLU, NCAM1, SYT17 and LTK were differentially expressed in responding tumor patients [119]. The induction of an immune response after allogeneic WT1 DC vaccination and donor lymphocyte infusion (DLI) in patients with hematologic malignancies and posttransplantation relapse demonstrated that vaccines could be successfully produced from samples from all donors. DC vaccination and DLI are well tolerated, and DC vaccines can be used to sensitize the repopulated allogeneic donor immune system to WT1 [120].

In a phase I clinical study in patients with follicular lymphoma (FL), Mo-DCs generated in the presence of IFN- $\alpha$ and GM-CSF (IFN-DC) in combination with low doses of rituximab were administered intranodally. The results indicated that IFN-DCs can synergize with rituximab leading to increased cytotoxicity and $\mathrm{T}$ cell tumor infiltration. The overall response rate was 50\% and the PET-negative complete response rate was $37 \%$. No grade 3 or higher AEs were observed [121]. As of the end of November 2021, there were 4 ongoing clinical trials with DC vaccines in patients with lymphoma, including intranodally or intratumorally administered vaccines, combined with immunotherapy, radiation or cryosurgery (Table 3).

\section{Methods for vaccine delivery}

A variety of methods to deliver DC-based vaccines to patients have been used, such as intravenous [48, 122, 123], intradermal [123-125] and less frequently intranodal $[48,126]$ and intratumoral routes [127-130], as well as in vivo DC induction [12] (Table 4). Currently, there is no consensus as to which route of dendritic cell administration is the best for effectively sensitizing $\mathrm{T}$ cells. While antigen-loaded DCs can prime T cell immunity regardless of the route, the quality of responses and induction of antigen-specific antibodies may be different depending upon the route of administration [128]. Intravenous administration of antigen-pulsed DCs and subcutaneous administration of immature DCs have been demonstrated to be effective methods for generating sensitized $\mathrm{T}$ cells $[131,132]$. In a mouse model, local carbon-ion radiotherapy combined with IV DCs augmented the immunogenicity of tumor cells and the maturation of DCs to stimulate antitumor immunity to decrease lung metastases [133]. In a phase I study using a $3+3$ dose escalation design, the immunogenicity and efficacy of an intravenous DC-targeted liposomal vaccine in twelve patients with metastatic cutaneous melanoma showed that the DC vaccine was well tolerated and did not induce clinically significant toxicity. Partial response and stable disease were observed in one and two patients, respectively [134].

Theoretically, intranodal administration of DCs may be the best route since DC migration is not required. In mouse models, compared to subcutaneous or intravenous immunization, intranodal injection of peptidepulsed DCs induced significantly greater expansion of antigen-specific $\mathrm{T}$ lymphocytes in the spleen and a stronger antigen-specific Th1-type response. Thus, intranodal administration was an effective and feasible method for DC vaccination [94]. It has been reported that intranodal vaccination with semimature DCs primed strong, long-lasting $\mathrm{CD} 4 \mathrm{~T}$ cell responses with a Th1-type cytokine profile in advanced melanoma patients [135]. All 5 metastatic melanoma patients in a tumor peptide-based DC vaccination trial developed strong and long-lasting delayed-type hypersensitivity reactivity correlated with the induction of CD4 T cell proliferation in vitro. In vitro stimulation results showed a significant increase in interferon $-\gamma$ and IL-2 
but not IL-4, IL-5, or IL-10 secretion by bulk T cells [135]. Similarly, intranodal administration of adenovirus encoding chimeric CD154 for CML [136], a tolerogenic DC-based vaccine for multiple sclerosis [137] and neoantigen peptide-loaded DC vaccines for ovarian cancer [138] has been reported. The results of a firstin-human phase I trial of intranodal direct injection of adenovirus expressing a chimeric CD154 molecule in fifteen patients with chronic lymphocytic leukemia (CLL) have been reported. The results showed that preliminary clinical responses, including reductions in leukemia cell counts, lymphadenopathy, and splenomegaly were observed. Six patients did not require additional therapy for more than 6 months, and three achieved a partial remission. These results provide rationale for phase II studies in patients with CLL, lymphomas, and CD40-expressing solid tumors [136]. A harmonized study protocol for two phase I clinical trials comparing intradermal and intranodal cell administration has been established, and clinical trials are underway [137]. Another trial demonstrated the clinical and immunological effects of neoantigen peptide-loaded DC-based immunotherapy in a patient with recurrent and chemoresistant ovarian cancer: following four rounds of vaccination with this therapy, CA-125 levels were remarkably decreased, tumor cells in ascites were decreased, and tumor-related symptoms such as respiratory discomfort improved without any adverse reactions [138]. However, studies on intranodal cell administration in AML/MDS patients are lacking.

Intratumoral administration of vaccines has been successfully used in solid tumors, such as breast, ovarian, lung, colorectal and renal cell carcinomas and melanoma. Intratumorally administration of TAAs in combination with immunostimulatory agents was able to activate tumor-infiltrating DCs and induce strong immune responses, resulting in tumor shrinkage or remission [139]. Based on this concept and these research results, TVEC has been approved by the US FDA for clinical use in patients with advanced malignant melanoma. While intratumoral administration of immunostimulatory agents and noncoding RNAs in solid tumors is a plausible method [140] and may remodel tumor metabolism and the immune microenvironment [141, 142], due to the pathogenesis of AML and MDS, intratumoral vaccination to locally activate tumor-infiltrating DCs may not be widely applicable except in the cases with chloroma as the only presentation.

\section{Enhancing DC vaccine efficacy via coadministration with chemotherapy and checkpoint inhibitors}

Hypomethylating agents (HMAs) alter the immune microenvironment in AML. Guadecitabine augments both antigen processing and presentation and increase AML susceptibility to $\mathrm{T}$ cell-mediated killing with increases $\mathrm{CD}^{+}$and $\mathrm{CD}^{+}$cells targeting syngeneic leukemia cells. Vaccination in conjunction with HMA therapy results in enhanced antileukemia immunity and survival [143]. Furthermore, vaccination with AML cell/ DC fusions elicits the expansion of leukemia-specific $T$ cells and protects against disease relapse. The combination of a personalized DC/AML cell fusion vaccine and an HMA demonstrated therapeutic potential [61]. The effects of decitabine on the allogeneic immune reaction were demonstrated in a murine model of DLI significantly greater tumor growth retardation and survival prolongation occurred in mice administered decitabine. Upon prompt DEC and DLI coadministration, DCs were activated, severe GVHD was induced, and survival was significantly decreased compared with DLI alone. The results suggest that DEC primes the allogeneic immune reactions of DLI via DC activation, and GVHD and GVL effects are separable through optimal DLI timing [144].

Studies have revealed that the combination of decitabine or guadecitabine with the NY-ESO-1 vaccine enhances vaccine immunogenicity in AML patients $[145,146]$. The de novo expressed NY-ESO-1 protein was naturally processed and presented in a time- and dose-dependent fashion up to 8 days after the start of DAC treatment, and converted the cell lines susceptible to antigen-specific recognition by $\mathrm{CD}^{+} \mathrm{T}$ cell clones [145]. $\mathrm{T}$ cells from AML patients treated with DC/AML cell fusion vaccine and guadecitabine displayed an increased capacity to lyse AML cells. In vitro studies also demonstrated that decitabine enhances NK cell-mediated cytotoxicity or CD123-specific chimeric antigen receptor $\mathrm{T}$ (CAR-T) cell antileukemic activities against AML [146]. In a phase I study, 9 patients with MDS received an HLA-unrestricted NY-ESO-1 vaccine on a nonoverlapping schedule every 4 weeks with standard-dose decitabine. The study demonstrated induction of NY-ESO-1 expression in 7 of 7 patients and NYESO-1-specific $\mathrm{CD}_{4}^{+}$and $\mathrm{CD} 8^{+} \mathrm{T}$-lymphocyte responses in 6 of 7 and 4 of 7 of the vaccinated patients, respectively. Vaccine responses were associated with a detectable population of CD $141^{\text {hi }}$ conventional DCs, indicating the potential for induced antigen-directed immunotherapy in MDS patients with limited options [147]. 
Table 4 Routes of dendritic cell vaccine administration

\begin{tabular}{|c|c|c|c|}
\hline $\begin{array}{l}\text { Routes of } \\
\text { DC vaccine } \\
\text { administration }\end{array}$ & Advantages & Disadvantages & Main references \\
\hline Intravenous infusion & $\begin{array}{l}\text { Best way for hematological malignancies } \\
\text { Can route DC vaccines to nonpreferred areas, e.g., } \\
\text { lungs, liver, spleen, bone marrow } \\
\text { Delivery of a precise number of DCs to the target T } \\
\text { cell compartment }\end{array}$ & $\begin{array}{l}\text { DCs need to go through the blood circulation to } \\
\text { reach the tumor sites }\end{array}$ & {$[48,122,123]$} \\
\hline Intradermal injection & $\begin{array}{l}\text { Most often used method } \\
\text { Administered near superficial lymph nodes } \\
\text { May give higher T cell responses than intravenous } \\
\text { injection }\end{array}$ & $\begin{array}{l}\text { Allows only } 5 \% \text { of DCs to reach the lymph nodes } \\
\text { Efficacy mainly depends on the migratory capacity } \\
\text { of DCs to the lymph nodes }\end{array}$ & [123-125] \\
\hline Intratumoral injection & $\begin{array}{l}\text { Mainly applied in solid tumor patients } \\
\text { Produces higher local vaccine concentrations } \\
\text { Directly activates infiltrating DCs in the tumor site } \\
\text { Easily primes the initial immune response }\end{array}$ & $\begin{array}{l}\text { Considered a traumatic method due to the puncture } \\
\text { process }\end{array}$ & {$[11,130]$} \\
\hline Intranodal injection & $\begin{array}{l}\text { Theoretically, may be the best route since DC migra- } \\
\text { tion is not required } \\
\text { Superiority over the other routes with regard to } \\
\text { sensitization of CD8+ T cells }\end{array}$ & $\begin{array}{l}\text { Extra skills are required to avoid lymph node damage } \\
\text { Not commonly used } \\
\text { Lack of pulications }\end{array}$ & {$[48,126]$} \\
\hline In vivo induction & $\begin{array}{l}\text { Administered with Kits. Activate the DCs in vivo } \\
\text { Activate both the innate and adaptive immune sys- } \\
\text { tem and especially leukemia specific T cells followed } \\
\text { by an immunoreaction against residual leukemic } \\
\text { blasts }\end{array}$ & $\begin{array}{l}\text { Difficult to check the quality and quantity of the DCs } \\
\text { May have individual reaction differences } \\
\text { More research is needed for validation }\end{array}$ & {$[12]$} \\
\hline
\end{tabular}

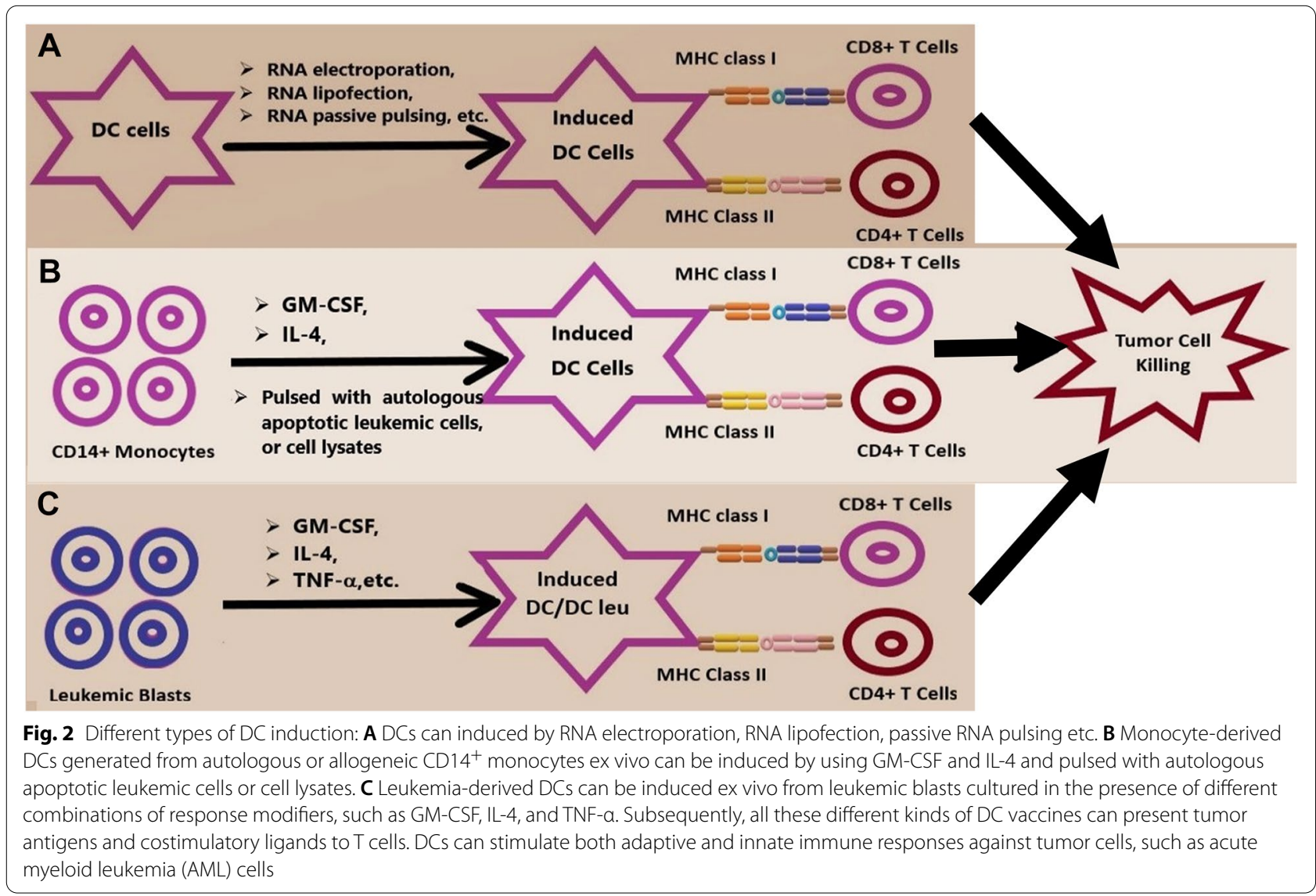


Another strategy to enhance DC vaccine efficacy is to combine DCs with immunomodulators targeting regulatory immune cells to overcome the immunosuppressive mechanisms of leukemia cells [42]. Previous studies have demonstrated that whole leukemia cell vaccines are suppressed by various immunosuppressive mechanisms of leukemia, including B7/cytotoxic $\mathrm{T}$ lymphocyte-associated protein 4 (CTLA4) and PD-1/PD-L1, Tregs, and myeloid-derived suppressor cells (MDSCs) [42, 148]. Therefore, blockade of the CTLA4 and PD-1 pathways could be used in combination with whole leukemia cell vaccines [42]. In a recent study, it was observed in a mouse model that $\mathrm{T}$ cell exhaustion in Langerhans cell histiocytosis was overcome with PD-1 blockade and targeted MAPK inhibition. The combination of a MAPK inhibitor and anti-PD-1 treatment significantly decreased both $\mathrm{CD}^{+} \mathrm{T}$ cells and myeloid Langerhans cells in a synergistic fashion. These results indicate that combined MAPK and checkpoint inhibition is a potential therapeutic strategy [149]. Therapeutic antibodies blocking the PD-1 pathway have been widely used in solid tumors [150]. DC/PD-1 immunotherapy combinations are currently under preclinical and clinical investigation in recurrent advanced brain tumors, advanced and relapsed NSCLC, MM and advanced renal cell carcinoma [151]. Additionally, various other combination therapies that exploit alternative immune targets and other therapeutic modalities have been explored for cancer treatment
[152-154], especially with the development of a new generation of immune checkpoint inhibitors and other inhibitory targets [155-161]. The combination of a DC/ AML cell fusion vaccine and checkpoint blocking therapy provides unique synergy to induce durable activation of leukemia specific immunity, protect against lethal tumor challenges, and selectively amplify tumor-reactive clones [162]. Different combinations designed to activate the endogenous $\mathrm{T}$ cell response through checkpoint blockade appear suitable and are being increasingly tested [163].

In some nonhematological malignancies, DC vaccines have shown an increase in the survival rate of patients in the late stage of tumor disease and have had a significant impact on the destruction of distant metastases. The combination of DC vaccines with another immunotherapy or traditional anticancer methods can be used in treating patients in the early stage of disease or preventing recurrence and metastasis [164].

Combining cancer vaccines with immunomodulatory drugs is currently regarded as a highly promising approach for boosting tumor-specific $\mathrm{T}$ cell immunity and eradicating residual malignant cells. Recently, a study of the FL mouse model with a new vaccine including IFN-DCs loaded with apoptotic lymphoma cells demonstrated that lenalidomide improves the therapeutic effect of an interferon- $\alpha$-dendritic cell-based lymphoma vaccine, which may lead to evaluation of the combination in clinical applications [165].

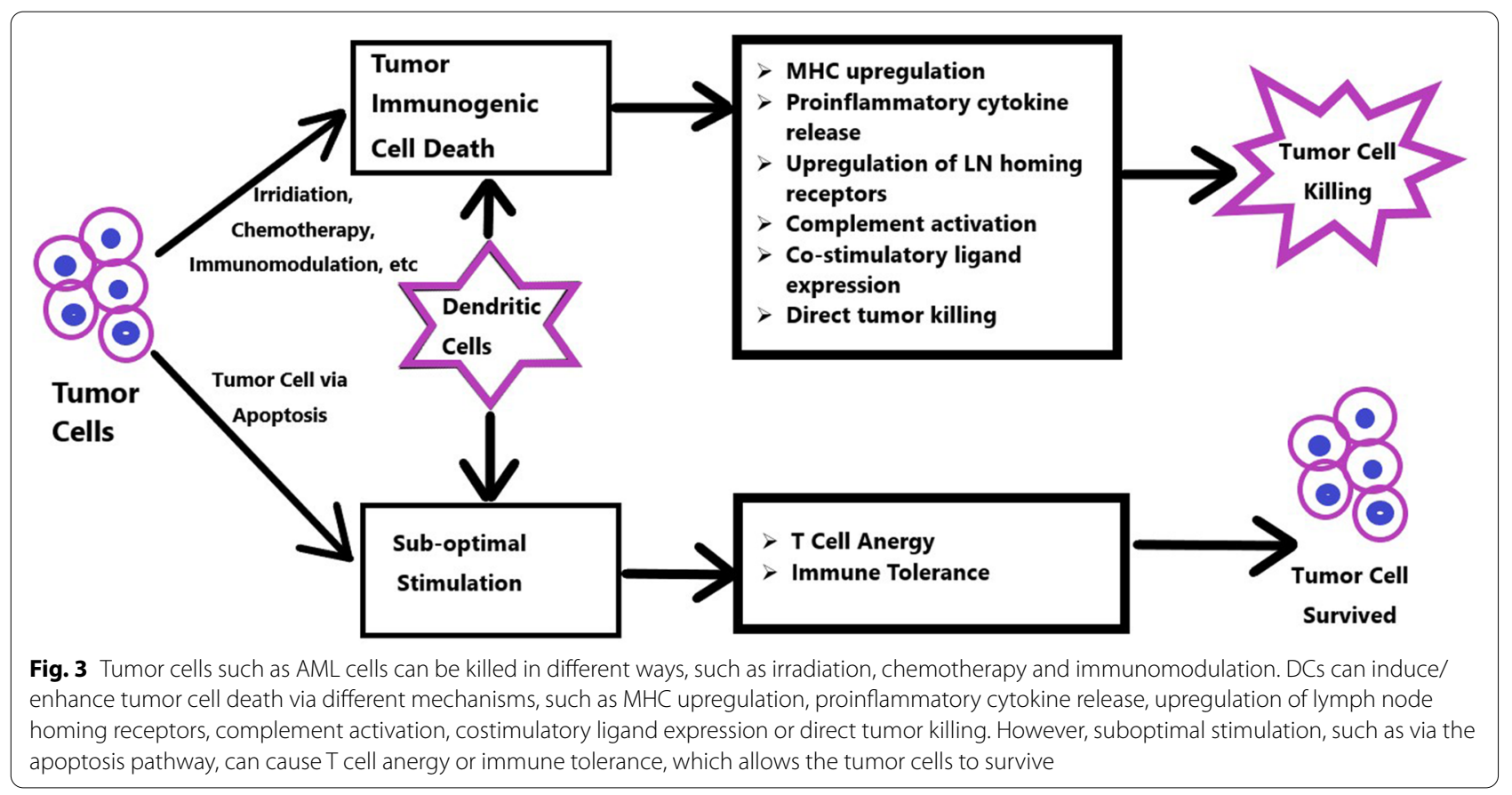




\section{Challenges of DC vaccines}

Although much progresses has been made in the field of DC vaccines, there are several challenges to the wider application of leukemic DC vaccines. In previous trials, failure to generate sufficient numbers of qualified AMLDCs was the most common reason for excluding patients from the study [46]. The high cost of the stimulants required to differentiate leukemic DCs was another challenge [42].

A critical lesson learned, however, is the insufficient therapeutic efficacy of vaccination using genetically modified GM-CSF-secreting leukemia DCs, which is probably due to the immunosuppressive effects of GM-CSF [166]. The lack of immunogenicity of the whole leukemia cell vaccine may be due to the immunosuppressive effect of phosphatidylserine (PS) exposure to inactivated immune responsive $\mathrm{T}$ cells [167]. However, studies have shown that inhibition of the PS recognition process increases the immunogenicity of irradiated lymphoma cells, suggesting that endogenous adjuvants combined with dying tumor cells can be used to target tumor immune rejection [168].

Immunosuppressive factors from malignant cells can impede the functions of both DCs and T cells and hinder the vaccine-generated protective immune response. Defects in hematopoietic progenitor cells and an abnormal bone marrow niche render hematopoiesis seriously ineffective in leukemia patients. These factors bring additional challenges and accentuate systemic immunosuppression and DC malfunction [66]. Overall, the objective response rate (ORR) of DC vaccine was reported to be approximately $15 \%$ [122]; its therapeutic efficacy has to be improved.

Different mechanisms of weak immunogenicity of DCs have been reported, including failure to induce leukemiaspecific CTLs [49], failure to activate NK cells or $\gamma \delta \mathrm{T}$ cells $[65,169,170]$, failure to overcome the immunosuppressive action of Tregs and MDSCs [171], and undesired immune effects from Tregs and MDSCs [172]. Therefore, novel strategies, including DC vaccines combined with HMAs [146], NK cell infusion or immune checkpoint blockade therapy in relapsed/refractory AML and highrisk MDS patients need to be further validated.

\section{Conclusions and future directions}

Many difficulties remain and prevent the widespread application of DC vaccine immunotherapy. These limitations include weak cellular immune responses, high costs and time-consuming processes [13]. Despite the limited clinical efficacy, DC vaccinations still constitute a promising new strategy for AML and MDS treatment, as well as the treatment of other malignancies $[13,66,164]$ with the validated safety and feasibility
[62]. In addition to DC vaccination combined with systemic monoclonal antibody and immune checkpoint blockades, incorporation of PD-1/PD-L signaling into DCs can enhance DC mediated activation of T/NK cells and prevent Tregs stimulation [150, 173]. With the increasing clinical efficacy and application of DCbased vaccine therapy in patients with solid tumors [174], there is increasing interest in combining DC vaccines with conventional therapy, such as HMAs in the frontline treatment of elderly AML patients [108]. A recent study demonstrated that transgelin-2 is an essential protein for cancer and immunity and can act as a double-edged sword for cancer therapy. Engineering and clinical application of this protein may lead to a new era of DC-based cancer immunotherapy [175]. We believe that use of a carefully designed personalized DC vaccine in combination with other appropriate treatment strategies may constitute a valuable option for future treatment of patients with AML/MDS and other malignancies.

\section{Abbreviations}

Allo-HSCT: Allogeneic hematopoietic stem cell transplantation; AML: Acute myeloid leukemia; APC: Antigen presenting cells; Apo-DC: Apoptotic CLL cells (Apo-DC); BDC: Blood dendritic cells; CALR: Calreticulin; CAR-T: Chimeric antigen receptor T cells; CCR7: Express chemokine receptor 7; CDCs: Conventional DCs; CLL: Chronic lymphocytic leukemia; CR: Complete remission; CR: Complete remission; CTL: Cytotoxic T-lymphocyte; CTLA4: Cytotoxic T-lymphocyte-associated protein 4; Dcleu: Leukemia-derived dendritic cells; DCs: Dendritic cells; DLI: Donor lymphocyte infusion; FISH: Fluorescence in situ hybridization; FL: Follicular lymphoma; GBM: Glioblastoma multiforme; GMP: Good Manufacturing Practice; GVL: Graft versus leukemia; HMA: Hypomethylating agents; HSCT: Hematopoietic stem cell transplantation; hTERT: Human telomerase reverse transcriptase; ICI: Immune checkpoint inhibitor; ICOSL: Inducible costimulatory molecule ligand; IFN-DC: DC subset differentiated with IFN-a; LAA: Leukemia-associated antigens; MDS: Myelodysplastic syndromes; MDSCs: Myeloid-derived suppressor cells; MHC: Major histocompatibility complex; MLC: Mixed-lymphocyte culture; Mo-DC: Monocyte-derived dendritic cells; NSCLC: Non-small cell lung cancer; ORR: Objective response rates; OS: Overall survival; PD-1: Programmed death 1; pDCs: Plasmacytoid DCs; PD-L1: Programmed death-ligand 1; PR: Partial remission; PRAME: Preferentially expressed antigen of melanoma; PS: Phosphatidylserine; TAA: Tumorassociated antigen; Tcms: Central memory T cells; Tems: Effector memory $T$ cells; TIL:Tumor-infiltrating lymphocyte; TME: Tumor microenvironment; TSA: Tumor-specific antigens; WT1: Wilms'tumor 1.

\section{Acknowledgements}

The authors would like to thank Dr. Peter Y. Z. Jiang at the Everett Clinic and Providence Regional Cancer Centre in Everett, Washington USA for critical review and suggestions.

\section{Authors' contributions}

$J Y$, HS designed and directed the study, and wrote the manuscript. WC, YS, and $Z J$ reviewed the manuscript. $Z J$ and YS provided resources. All authors reviewed the final manuscript. All authors read and approved the final manuscript.

\section{Funding}

This work was supported by the Project of Henan Provincial Education Department, China (20A320062, recipient JY), Project of Science and Technology Department of Henan Province, China (LHGJ20190039, recipient JY), Project of Science and Technology Department of Henan Province, China (SBGJ20202076, recipient JY), and Talent Research Fund of the First Affiliated 
Hospital of Zhengzhou University, Zhengzhou, China (recipient JY). The fund ing bodies did not participate in the study design, in data collection, analysis, and interpretation, and in writing the manuscript.

\section{Availability of data and materials}

All clinical trials related information was obtained from public databases.

\section{Declarations}

Ethics approval and consent to participate

Not applicable.

\section{Consent for publication}

Not applicable.

\section{Competing interests}

The authors declare no conflict of interest.

\section{Author details}

${ }^{1}$ The First Affiliated Hospital of Zhengzhou University, Zhengzhou 450052, Henan, China. ${ }^{2}$ Henan International Joint Laboratory of Nuclear Protein Gene Regulation, Henan University College of Medicine, Kaifeng 475004, Henan, China. ${ }^{3}$ Department of Hematology, The Affiliated Cancer Hospital of Zhengzhou University and Henan Cancer Hospital, Zhengzhou 450008, Henan, China.

Received: 7 September 2021 Accepted: 16 January 2022

Published online: 24 January 2022

\section{References}

1. Döhner $H$, Weisdorf DJ, Bloomfield CD. Acute myeloid leukemia. N Engl J Med. 2015;373(12):1136-52.

2. Cazzola M. Myelodysplastic syndromes. N Engl J Med. 2020;383(14):1358-74

3. Löwenberg B, Downing JR, Burnett A. Acute myeloid leukemia. N Engl J Med. 1999;341(14):1051-62.

4. Döhner H, Estey E, Grimwade D, Amadori S, Appelbaum FR, Büchner T, et al. Diagnosis and management of AML in adults: 2017 ELN recommendations from an international expert panel. Blood. 2017:129(4):424-47.

5. O'Donnell MR, Tallman MS, Abboud CN, Altman JK, Appelbaum FR, Arber DA, et al. Acute myeloid leukemia, version 3.2017, NCCN clinical practice guidelines in oncology. JNCCN. 2017;15(7):926-57.

6. Kahl C, Krahl R, Becker C, Al-Ali HK, Sayer HG, Schulze A, et al. Long-term follow-up of the AML97 study for patients aged 60 years and above with acute myeloid leukaemia: a study of the East German Haematology and Oncology Study Group (OSHO). J Cancer Res Clin Oncol. 2016;142(1):305-15

7. Short NJ, Konopleva M, Kadia TM, Borthakur G, Ravandi F, DiNardo CD, et al. Advances in the treatment of acute myeloid leukemia: new drugs and new challenges. Cancer Discov. 2020;10(4):506-25.

8. Champlin R. Reduced intensity allogeneic hematopoietic transplantation is an established standard of care for treatment of older patients with acute myeloid leukemia. Best Pract Res Clin Haematol. 2013:26(3):297-300

9. Jiang Y-Z. Effector cells and mechanisms of the GVL effect. In: Allogeneic immunotherapy for malignant diseases. 1st ed. New York: Marcel Dekker; 2000. p. 44-50.

10. Powles RL, Russell J, Lister TA, Oliver T, Whitehouse JM, Malpas J, et al. Immunotherapy for acute myelogenous leukaemia: a controlled clinical study $21 / 2$ years after entry of the last patient. Br J Cancer. 1977;35(3):265-72.

11. Harari A, Graciotti M, Bassani-Sternberg M, Kandalaft LE. Antitumour dendritic cell vaccination in a priming and boosting approach. Nat Rev Drug Discov. 2020;19(9):635-52.

12. Amberger DC, Schmetzer HM. Dendritic cells of leukemic origin: specialized antigen-presenting cells as potential treatment tools for patients with myeloid leukemia. Transfus Med Hemother. 2020;47(6):432-43.

13. Wculek SK, Cueto FJ, Mujal AM, Melero I, Krummel MF, Sancho D. Dendritic cells in cancer immunology and immunotherapy. Nat Rev Immunol. 2020;20(1):7-24.

14. Wan H, Dupasquier M. Dendritic cells in vivo and in vitro. Cell Mol Immunol. 2005:2(1):28-35.

15. Durai V, Murphy KM. Functions of murine dendritic cells. Immunity. 2016:45(4):719-36.

16. Reuther S, Schmetzer H, Schuster FR, Krell P, Grabrucker C, Liepert A, et al. In vitro-induced response patterns of antileukemic T cells: characterization by spectratyping and immunophenotyping. Clin Exp Med. 2013;13(1):29-48

17. Wang $Y$, Xiang $Y$, Xin VW, Wang $X W$, Peng $X C$, Liu $X Q$, et al. Dendritic cell biology and its role in tumor immunotherapy. J Hematol Oncol. 2020;13(1):107.

18. Bordon Y. Dendritic cells: sorting, sorted! Nat Rev Immunol. 2016:16(11):657.

19. Guilliams M, Dutertre CA, Scott CL, McGovern N, Sichien D, Chakarov $\mathrm{S}$, et al. Unsupervised high-dimensional analysis aligns dendritic cells across tissues and species. Immunity. 2016;45(3):669-84.

20. Van Acker HH, Versteven M, Lichtenegger FS, Roex G, Campillo-Davo D, Lion E, et al. Dendritic cell-based immunotherapy of acute myeloid leukemia. J Clin Med. 2019;8(5):579.

21. Steger B, Floro L, Amberger DC, Kroell T, Tischer J, Kolb HJ, et al. WT1, PRAME, and PR3 mRNA expression in acute myeloid leukemia (AML). J Immunother. 2020:43(6):204-15.

22. Sabado RL, Balan S, Bhardwaj N. Dendritic cell-based immunotherapy. Cell Res. 2017;27(1):74-95.

23. Schürch CM, Riether C, Ochsenbein AF. Dendritic cell-based immunotherapy for myeloid leukemias. Front Immunol. 2013:4:496.

24. Anguille S, Willemen $Y$, Lion E, Smits EL, Berneman ZN. Dendritic cell vaccination in acute myeloid leukemia. Cytotherapy. 2012;14(6):647-56.

25. Usero L, Miralles L, Esteban I, Pastor-Quiñones C, Maleno MJ, Leal L, et al. Feasibility of using monocyte-derived dendritic cells obtained from cryopreserved cells for DC-based vaccines. J Immunol Methods. 2021:498: 113133.

26. Lee JJ, Kook H, Park MS, Nam JH, Choi BH, Song WH, et al. Immunotherapy using autologous monocyte-derived dendritic cells pulsed with leukemic cell lysates for acute myeloid leukemia relapse after autologous peripheral blood stem cell transplantation. J Clin Apheresis. 2004;19(2):66-70.

27. Amberger DC, Doraneh-Gard F, Gunsilius C, Weinmann M, Möbius S, Kugler C, et al. PGE(1)-containing protocols generate mature (leukemia-derived) dendritic cells directly from leukemic whole blood. Int J Mol Sci. 2019;20(18):4590.

28. Hirn Lopez A, Deen D, Fischer Z, Rabe A, Ansprenger C, Stein K, et al. Role of linterferon (IFN)a in "cocktails" for the generation of (leukemia-derived) dendritic cells (DCleu) from blasts in blood from patients (pts) with acute myeloid leukemia (AML) and the induction of antileukemic reactions. J Immunother. 2019;42(5):143-61.

29. Nourizadeh M, Masoumi F, Memarian A, Alimoghaddam K, Moazzeni SM, Yaghmaie $M$, et al. In vitro induction of potent tumor-specific cytotoxic T lymphocytes using TLR agonist-activated AML-DC. Target Oncol. 2014;9(3):225-37.

30. Westers TM, Ossenkoppele GJ, van de Loosdrecht AA. Dendritic cell-based immunotherapy in acute and chronic myeloid leukaemia. Biomed Pharmacother. 2007;61(6):306-14.

31. Kremser A, Dressig J, Grabrucker C, Liepert A, Kroell T, Scholl N, et al. Dendritic cells (DCs) can be successfully generated from leukemic blasts in individual patients with AML or MDS: an evaluation of different methods. J Immunother. 2010;33(2):185-99.

32. Pyzer AR, Avigan DE, Rosenblatt J. Clinical trials of dendritic cellbased cancer vaccines in hematologic malignancies. Hum Vaccines Immunother. 2014;10(11):3125-31.

33. Kremser A, Kufner S, Konhaeuser E, Kroell T, Hausmann A, Tischer J, et al. Combined immunophenotyping and fluorescence in situ hybridization with chromosome-specific DNA probes allows quantification and differentiation of ex vivo generated dendritic cells, 
leukemia-derived dendritic cells and clonal leukemic cells in patients with acute myeloid leukemia. Leuk Lymphoma. 2013;54(6):1297-308.

34. Schmetzer HM, Kremser A, Loibl J, Kroell T, Kolb HJ. Quantification of ex vivo generated dendritic cells (DC) and leukemia-derived DC contributes to estimate the quality of DC, to detect optimal DCgenerating methods or to optimize DC-mediated T-cell-activationprocedures ex vivo or in vivo. Leukemia. 2007;21(6):1338-41.

35. Dreyssig J, Kremser A, Liepert A, Grabrucker C, Freudenreich M, Schmid C, et al. Various 'dendritic cell antigens' are already expressed on uncultured blasts in acute myeloid leukemia and myelodysplastic syndromes. Immunotherapy. 2011;3(9):1113-24.

36. Platt AM, Randolph GJ. Dendritic cell migration through the lymphatic vasculature to lymph nodes. Adv Immunol. 2013;120:51-68.

37. Li Z, Ju X, Silveira PA, Abadir E, Hsu WH, Hart DNJ, et al. CD83: activation marker for antigen presenting cells and its therapeutic potential. Front Immunol. 2019;10:1312.

38. Zheng Z, Takahashi M, Aoki S, Toba K, Liu A, Osman Y, et al. Expression patterns of costimulatory molecules on cells derived from human hematological malignancies. J Exp Clin Cancer Res. 1998;17(3):251-8.

39. Schmitt M, Li L, Giannopoulos K, Chen J, Brunner C, Barth T, et al. Chronic myeloid leukemia cells express tumor-associated antigens eliciting specific CD8+ T-cell responses and are lacking costimulatory molecules. Exp Hematol. 2006;34(12):1709-19.

40. Cardoso AA, Schultze JL, Boussiotis VA, Freeman GJ, Seamon MJ, Laszlo $\mathrm{S}$, et al. Pre-B acute lymphoblastic leukemia cells may induce T-cell anergy to alloantigen. Blood. 1996;88(1):41-8.

41. Narita M, Takahashi M, Liu A, Nikkuni K, Furukawa T, Toba K, et al. Leukemia blast-induced T-cell anergy demonstrated by leukemiaderived dendritic cells in acute myelogenous leukemia. Exp Hematol. 2001;29(6):709-19.

42. Ji YS, Park SK, Ryu S. Whole leukemia cell vaccines: past progress and future directions. Vaccine. 2020;38(22):3811-20.

43. Choudhury BA, Liang JC, Thomas EK, Flores-Romo L, Xie QS, Agusala K, et al. Dendritic cells derived in vitro from acute myelogenous leukemia cells stimulate autologous, antileukemic T-cell responses. Blood. 1999;93(3):780-6.

44. Cignetti A, Vallario A, Roato I, Circosta P, Allione B, Casorzo L, et al. Leukemia-derived immature dendritic cells differentiate into functionally competent mature dendritic cells that efficiently stimulate T cell responses. J Immunol. 2004;173(4):2855-65.

45. Westers TM, Houtenbos I, Snoijs NC, van de Loosdrecht AA, Ossenkoppele GJ. Leukemia-derived dendritic cells in acute myeloid leukemia exhibit potent migratory capacity. Leukemia. 2005;19(7):1270-2.

46. Roddie H, Klammer M, Thomas C, Thomson R, Atkinson A, Sproul A, et al. Phase I/II study of vaccination with dendritic-like leukaemia cells for the immunotherapy of acute myeloid leukaemia. Br J Haematol. 2006;133(2):152-7.

47. Li L, Giannopoulos K, Reinhardt P, Tabarkiewicz J, Schmitt A, Greiner J, et al. Immunotherapy for patients with acute myeloid leukemia using autologous dendritic cells generated from leukemic blasts. Int J Oncol. 2006;28(4):855-61.

48. Tesfatsion DA. Dendritic cell vaccine against leukemia: advances and perspectives. Immunotherapy. 2014;6(4):485-96.

49. Kitawaki T, Kadowaki N, Fukunaga K, Kasai Y, Maekawa T, Ohmori K, et al. A phase I/lla clinical trial of immunotherapy for elderly patients with acute myeloid leukaemia using dendritic cells co-pulsed with WT peptide and zoledronate. Br J Haematol. 2011;153(6):796-9.

50. Greiner J, Schmitt A, Giannopoulos K, Rojewski MT, Götz M, Funk I, Ringhoffer M, Bunjes D, Hofmann S, Ritter G, Döhner H, Schmitt M. High-dose RHAMM-R3 peptide vaccination for patients with acute myeloid leukemia, myelodysplastic syndrome and multiple myeloma. Haematologica. 2010;95(7):1191-7.

51. Palma M, Hansson L, Choudhury A, Näsman-Glaser B, Eriksson I, Adamson L, Rossmann E, Widén K, Horváth R, Kokhaei P, Vertuani S, Mellstedt $\mathrm{H}$, Osterborg A. Vaccination with dendritic cells loaded with tumor apoptotic bodies (Apo-DC) in patients with chronic lymphocytic leukemia: effects of various adjuvants and definition of immune response criteria. Cancer Immunol Immunother. 2011:61 (6):865-79.

52. Chung DJRE, Pronschinske KB, Shyer JA, Mennecozzi M, StAngelo ET, Young JW. Langerhanstype and monocyte-derived human dendritic cells have different susceptibilities to mRNA electroporation with distinct effects on maturation and activation: implications for immunogenicity in dendritic cell-based immunotherapy. J Transl Med. 2013:11:166.

53. Stripecke R, Cardoso AA, Pepper KA, Skelton DC, Yu XJ, Mascarenhas L, et al. Lentiviral vectors for efficient delivery of CD80 and granulocytemacrophage-colony-stimulating factor in human acute lymphoblastic leukemia and acute myeloid leukemia cells to induce antileukemic immune responses. Blood. 2000;96(4):1317-26.

54. Briones J, Timmerman JM, Panicalli DL, Levy R. Antitumor immunity after vaccination with B lymphoma cells overexpressing a triad of costimulatory molecules. J Natl Cancer Inst. 2003;95(7):548-55.

55. Litzinger MT, Foon KA, Sabzevari H, Tsang KY, Schlom J, Palena C. Chronic lymphocytic leukemia (CLL) cells genetically modified to express B7-1, ICAM-1, and LFA-3 confer APC capacity to T cells from CLL patients. Cancer Immunol Immunother CII. 2009;58(6):955-65.

56. Vogt V, Schick J, Ansprenger C, Braeu M, Kroell T, Kraemer D, et al. Profiles of activation, differentiation-markers, or $\beta$-integrins on $T$ cells contribute to predict T cells' antileukemic responses after stimulation with leukemia-derived dendritic cells. J Immunother. 2014;37(6):331-47.

57. Schick J, Vogt V, Zerwes M, Kroell T, Kraemer D, Köhne CH, et al. Antileukemic T-cell responses can be predicted by the composition of specific regulatory T-cell subpopulations. J Immunother. 2013;36(4):223-37.

58. Grabrucker C, Liepert A, Dreyig J, Kremser A, Kroell T, Freudenreich M, et al. The quality and quantity of leukemia-derived dendritic cells from patients with acute myeloid leukemia and myelodysplastic syndrome are a predictive factor for the lytic potential of dendritic cells-primed leukemia-specific T cells. J Immunother. 2010;33(5):523-37.

59. Dong M, Liang D, Li Y, Kong D, Kang P, Li K, et al. Autologous dendritic cells combined with cytokine-induced killer cells synergize low-dose chemotherapy in elderly patients with acute myeloid leukaemia. J Int Med Res. 2012:40(4):1265-74.

60. van de Loosdrecht AA, van Wetering S, Santegoets S, Singh SK, Eeltink CM, den Hartog Y, et al. A novel allogeneic off-the-shelf dendritic cell vaccine for post-remission treatment of elderly patients with acute myeloid leukemia. Cancer Immunol Immunother CII. 2018;67(10):1505-18

61. Rosenblatt J, Stone RM, Uhl L, Neuberg D, Joyce R, Levine JD, et al. Individualized vaccination of AML patients in remission is associated with induction of antileukemia immunity and prolonged remissions. Sci Transl Med. 2016:8(368): 368ra171.

62. Anguille S, Smits EL, Cools N, Goossens H, Berneman ZN, Van Tendeloo VF. Short-term cultured, interleukin-15 differentiated dendritic cells have potent immunostimulatory properties. J TransI Med. 2009;7:109.

63. Anguille S, Lion E, Tel J, de Vries IJ, Couderé K, Fromm PD, et al. Interleukin-15-induced CD56(+) myeloid dendritic cells combine potent tumor antigen presentation with direct tumoricidal potential. PLOS ONE. 2012;7(12): e51851.

64. Anguille S, Van Acker HH, Van den Bergh J, Willemen Y, Goossens H, Van Tendeloo VF, et al. Interleukin-15 dendritic cells harness NK cell cytotoxic effector function in a contact- and IL-15-dependent manner. PLOS ONE. 2015:10(5): e0123340.

65. Van Acker HH, Anguille S, De Reu H, Berneman ZN, Smits EL, Van Tendeloo VF. Interleukin-15-cultured dendritic cells enhance anti-tumor gamma delta T cell functions through IL-15 secretion. Front Immunol. 2018:9:658.

66. O'Brien LJ, Guillerey C, Radford KJ. Can dendritic cell vaccination prevent leukemia relapse? Cancers. 2019;11(6):875.

67. Mehta HM, Malandra M, Corey SJ. G-CSF and GM-CSF in neutropenia. J Immunol. 2015;195(4):1341-9.

68. Pitt JM, André F, Amigorena S, Soria JC, Eggermont A, Kroemer G, et al. Dendritic cell-derived exosomes for cancer therapy. J Clin Investig. 2016;126(4):1224-32.

69. Fischbacher D, Merle M, Liepert A, Grabrucker C, Kroell T, Kremser A, et al. Cytokine release patterns in mixed lymphocyte culture (MLC) of T-cells with dendritic cells (DC) generated from AML blasts contribute to predict anti-leukaemic T-cell reactions and patients'13 response to immunotherapy. Cell Commun Adhes. 2015;22(2-6):49-65.

70. Benites BD, da Silva Santos Duarte A, Longhini ALF, Santos I, Alvarez MC, de Morais Ribeiro LN, et al. Exosomes in the serum of acute myeloid leukemia patients induce dendritic cell tolerance: implications for immunotherapy. Vaccine. 2019;37(11):1377-83. 
71. Yao Y, Wang C, Wei W, Shen C, Deng X, Chen L, et al. Dendritic cells pulsed with leukemia cell-derived exosomes more efficiently induce antileukemic immunities. PLoS ONE. 2014;9(3): e91463.

72. Chevallier P, Saiagh S, Dehame V, Guillaume T, Peterlin P, Bercegeay $S$, et al. A phase I/II feasibility vaccine study by autologous leukemic apoptotic corpse-pulsed dendritic cells for elderly AML patients. Hum Vaccines Immunother. 2021. https://doi.org/10.1080/21645515.2021. 1943991.

73. Hoffmann JM, Schmitt M, Ni M, Schmitt A. Next-generation dendritic cell-based vaccines for leukemia patients. Immunotherapy. 2017;9(2):173-81.

74. Odunsi K, Qian F, Matsuzaki J, Mhawech-Fauceglia P, Andrews C, Hoffman EW, et al. Vaccination with an NY-ESO-1 peptide of HLA class I/II specificities induces integrated humoral and T cell responses in ovarian cancer. Proc Natl Acad Sci USA. 2007;104(31):12837-42.

75. Chiang $\mathrm{CL}$, Benencia F, Coukos $\mathrm{G}$. Whole tumor antigen vaccines. Semin Immunol. 2010;22(3):132-43.

76. Copier J, Dalgleish A. Overview of tumor cell-based vaccines. Int Rev Immunol. 2006;25(5-6):297-319.

77. Brayer J, Lancet JE, Powers J, List A, Balducci L, Komrokji R, et al. WT1 vaccination in AML and MDS: a pilot trial with synthetic analog peptides. Am J Hematol. 2015;90(7):602-7.

78. Di Stasi A, Jimenez AM, Minagawa K, Al-Obaidi M, Rezvani K. Review of the results of WT1 peptide vaccination strategies for myelodysplastic syndromes and acute myeloid leukemia from nine different studies. Front Immunol. 2015;6:36

79. Subklewe M, Geiger C, Lichtenegger FS, Javorovic M, Kvalheim G, Schendel DJ, et al. New generation dendritic cell vaccine for immunotherapy of acute myeloid leukemia. Cancer Immunol Immunother CII. 2014;63(10):1093-103

80. Van Tendeloo VF, Van de Velde A, Van Driessche A, Cools N, Anguille S, Ladell $\mathrm{K}$, et al. Induction of complete and molecular remissions in acute myeloid leukemia by Wilms' tumor 1 antigen-targeted dendritic cell vaccination. Proc Natl Acad Sci USA. 2010;107(31):13824-9.

81. Lee DW, Kochenderfer JN, Stetler-Stevenson M, Cui YK, Delbrook C, Feldman SA, et al. T cells expressing CD19 chimeric antigen receptors for acute lymphoblastic leukaemia in children and young adults: a phase 1 dose-escalation trial. Lancet. 2015;385(9967):517-28.

82. Porter DL, Hwang WT, Frey NV, Lacey SF, Shaw PA, Loren AW, et al. Chimeric antigen receptor $T$ cells persist and induce sustained remissions in relapsed refractory chronic lymphocytic leukemia. Sci Transl Med. 2015:7(303): 303ra139.

83. Topalian SL, Hodi FS, Brahmer JR, Gettinger SN, Smith DC, McDermott DF, et al. Safety, activity, and immune correlates of anti-PD-1 antibody in cancer. N Engl J Med. 2012;366(26):2443-54.

84. Oka Y, Tsuboi A, Taguchi T, Osaki T, Kyo T, Nakajima H, et al. Induction of WT1 (Wilms' tumor gene)-specific cytotoxic T lymphocytes by WT1 peptide vaccine and the resultant cancer regression. Proc Natl Acad Sci USA. 2004;101(38):13885-90.

85. Schmitt M, Schmitt A, Rojewski MT, Chen J, Giannopoulos K, Fei F, et al. RHAMM-R3 peptide vaccination in patients with acute myeloid leukemia, myelodysplastic syndrome, and multiple myeloma elicits immunologic and clinical responses. Blood. 2008;111(3):1357-65.

86. Keilholz U, Letsch A, Busse A, Asemissen AM, Bauer S, Blau IW, et al. A clinical and immunologic phase 2 trial of Wilms tumor gene product 1 (WT1) peptide vaccination in patients with AML and MDS. Blood. 2009;113(26):6541-8.

87. Stroopinsky D, Rosenblatt J, Ito K, Mills H, Yin L, Rajabi H, et al. MUC1 is a potential target for the treatment of acute myeloid leukemia stem cells. Can Res. 2013:73(17):5569-79.

88. Liu J, Zhang S, Hu Y, Yang Z, Li J, Liu X, et al. Targeting PD-1 and Tim-3 pathways to reverse CD8 T-cell exhaustion and enhance ex vivo T-cell responses to autologous dendritic/tumor vaccines. J Immunother. 2016:39(4):171-80.

89. Stroopinsky D, Liegel J, Bhasin M, Cheloni G, Thomas B, Bhasin S, et al. Leukemia vaccine overcomes limitations of checkpoint blockade by evoking clonal T cell responses in a murine acute myeloid leukemia model. Haematologica. 2021;106(5):1330.

90. Bernal-Estévez DA, Ortíz Barbosa MA, Ortíz-Montero P, Cifuentes C, Sánchez R, Parra-López CA. Autologous dendritic cells in combination with chemotherapy restore responsiveness of T cells in breast cancer patients: a single-arm phase I/II trial. Front Immunol. 2021;12: 669965

91. Galati D, Zanotta S, Bocchino M, De Filippi R, Pinto A. The subtle interplay between gamma delta T lymphocytes and dendritic cells: is there a role for a therapeutic cancer vaccine in the era of combinatorial strategies? Cancer Immunol Immunother CII. 2021;70:1797-809.

92. Anguille S, Van de Velde AL, Smits EL, Van Tendeloo VF, Juliusson G, Cools N, et al. Dendritic cell vaccination as postremission treatment to prevent or delay relapse in acute myeloid leukemia. Blood. 2017;130(15):1713-21.

93. Dörrie J, Schaft N, Schuler G, Schuler-Thurner B. Therapeutic cancer vaccination with ex vivo RNA-transfected dendritic cells - an update. Pharmaceutics. 2020;12(2):92.

94. Schmitt A, Hus I, Schmitt M. Dendritic cell vaccines for leukemia patients. Expert Rev Anticancer Ther. 2007;7(3):275-83.

95. Tang L, Zhang R, Zhang X, Yang L. Personalized neoantigen-pulsed DC vaccines: advances in clinical applications. Front Oncol. 2021;11: 701777.

96. Bulgarelli J, Tazzari M, Granato AM, Ridolfi L, Maiocchi S, de Rosa F, et al. Dendritic cell vaccination in metastatic melanoma turns "non-T cell inflamed" into "T-cell inflamed" tumors. Front Immunol. 2019;10:2353.

97. van Willigen WW, Bloemendal M, Boers-Sonderen MJ, de Groot JWB, Koornstra RHT, van der Veldt AAM, et al. Response and survival of metastatic melanoma patients treated with immune checkpoint inhibition for recurrent disease on adjuvant dendritic cell vaccination. Oncoimmunology. 2020;9(1):1738814.

98. Lövgren T, Wolodarski M, Wickström S, Edbäck U, Wallin M, Martell E, et al. Complete and long-lasting clinical responses in immune checkpoint inhibitor-resistant, metastasized melanoma treated with adoptive T cell transfer combined with DC vaccination. Oncoimmunology. 2020:9(1):1792058.

99. Saberian C, Amaria RN, Najjar AM, Radvanyi LG, Haymaker CL, Forget $M A$, et al. Randomized phase II trial of lymphodepletion plus adoptive cell transfer of tumor-infiltrating lymphocytes, with or without dendritic cell vaccination, in patients with metastatic melanoma. J Immunother Cancer. 2021;9(5): e002449.

100. Maurer DM, Adamik J, Santos PM, Shi J, Shurin MR, Kirkwood JM, et al. Dysregulated NF-KB-dependent ICOSL expression in human dendritic cell vaccines impairs T-cell responses in patients with melanoma. Cancer Immunol Res. 2020;8(12):1554-67.

101. Jansen Y, Kruse V, Corthals J, Schats K, van Dam PJ, Seremet T, et al. A randomized controlled phase II clinical trial on mRNA electroporated autologous monocyte-derived dendritic cells (TriMixDC-MEL) as adjuvant treatment for stage III/IV melanoma patients who are diseasefree following the resection of macrometastases. Cancer Immunol Immunother CII. 2020;69(12):2589-98.

102. Boudewijns S, Bloemendal M, de Haas N, Westdorp H, Bol KF, Schreibelt $\mathrm{G}$, et al. Autologous monocyte-derived DC vaccination combined with cisplatin in stage III and IV melanoma patients: a prospective, randomized phase 2 trial. Cancer Immunol Immunother CII. 2020;69(3):477-88.

103. Datsi A, Sorg RV. Dendritic cell vaccination of glioblastoma: road to success or dead end. Front Immunol. 2021:12: 770390

104. Liau LM, Ashkan K, Tran DD, Campian JL, Trusheim JE, Cobbs CS, et al. First results on survival from a large phase 3 clinical trial of an autologous dendritic cell vaccine in newly diagnosed glioblastoma. J Transl Med. 2018;16(1):142.

105. Wang QT, Nie Y, Sun SN, Lin T, Han RJ, Jiang J, et al. Tumor-associated antigen-based personalized dendritic cell vaccine in solid tumor patients. Cancer Immunol Immunother CII. 2020;69(7):1375-87.

106. Mitsuya K, Akiyama Y, lizuka A, Miyata H, Deguchi S, Hayashi N, et al. Alpha-type-1 polarized dendritic cell-based vaccination in newly diagnosed high-grade glioma: a phase II clinical trial. Anticancer Res. 2020:40(11):6473-84.

107. Tan L, Peng J, Liu P, Wu Q. The efficacy of dendritic cell vaccine for newly diagnosed glioblastoma: a meta-analysis of randomized controlled studies. Clin Neuropharmacol. 2021;44(6):216-21.

108. Liu Z, Gao C, Tian J, Ma T, Cao X, Li A. The efficacy of dendritic cell vaccine for newly diagnosed glioblastoma: a meta-analysis of randomized controlled studies. Neurochirurgie. 2021;67(5):433-8. 
109. Chen R, Huang M, Yang X, Chen XH, Shi MY, Li ZF, et al. CALR-TLR4 complex inhibits non-small cell lung cancer progression by regulating the migration and maturation of dendritic cells. Front Oncol. 2021;11: 743050 .

110. Ding Z, Li Q, Zhang R, Xie L, Shu Y, Gao S, et al. Personalized neoantigen pulsed dendritic cell vaccine for advanced lung cancer. Signal Transduct Target Ther. 2021;6(1):26.

111. Chiappori AA, Williams CC, Gray JE, Tanvetyanon T, Haura EB, Creelan $B C$, et al. Randomized-controlled phase II trial of salvage chemotherapy after immunization with a TP53-transfected dendritic cell-based vaccine (Ad.p53-DC) in patients with recurrent small cell lung cancer. Cancer Immunol Immunother CII. 2019:68(3):517-27.

112. Ingels J, De Cock L, Mayer RL, Devreker P, Weening K, Heyns K, et al. Small-scale manufacturing of neoantigen-encoding messenger RNA for early-phase clinical trials. Cytotherapy. 2021. https://doi.org/10.1016/j. jcyt.2021.08.005.

113. El-Ashmawy NE, Salem ML, Abd El-Fattah EE, Khedr EG. Targeting CD166(+) lung cancer stem cells: molecular study using murine dendritic cell vaccine. Toxicol Appl Pharmacol. 2021;429: 115699.

114. Shi W, Yang X, Xie S, Zhong D, Lin X, Ding Z, et al. A new PD-1-specific nanobody enhances the antitumor activity of T-cells in synergy with dendritic cell vaccine. Cancer Lett. 2021:522:184-97.

115. Pan RY, Chung WH, Chu MT, Chen SJ, Chen HC, Zheng L, et al. Recent development and clinical application of cancer vaccine: targeting neoantigens. J Immunol Res. 2018;2018:4325874.

116. Sutherland SIM, Ju X, Horvath LG, Clark GJ. Moving on from sipuleucel$\mathrm{T}$ : new dendritic cell vaccine strategies for prostate cancer. Front Immunol. 2021;12:641307.

117. Sonpavde G, McMannis JD, Bai Y, Seethammagari MR, Bull JMC, Hawkins $\checkmark$, et al. Phase I trial of antigen-targeted autologous dendritic cell-based vaccine with in vivo activation of inducible CD40 for advanced prostate cancer. Cancer Immunol Immunother CII. 2017;66(10):1345-57.

118. Tryggestad AMA, Axcrona K, Axcrona U, Bigalke I, Brennhovd B, Inderberg EM, et al. Long-term first-in-man phase I/II study of an adjuvant dendritic cell vaccine in patients with high-risk prostate cancer after radical prostatectomy. Prostate. 2021;82(2):245-53.

119. Fucà G, Ambrosini M, Agnelli L, Brich S, Sgambelluri F, Mortarini R, et al. Fifteen-year follow-up of relapsed indolent non-Hodgkin lymphoma patients vaccinated with tumor-loaded dendritic cells. J Immunother Cancer. 2021;9(6): e002240.

120. Shah NN, Loeb DM, Khuu H, Stroncek D, Ariyo T, Raffeld M, et al. Induction of immune response after allogeneic Wilms'tumor 1 dendritic cell vaccination and donor lymphocyte infusion in patients with hematologic malignancies and post-transplantation relapse. Biol Blood Marrow Transplant. 2016:22(12):2149-54.

121. Cox MC, Castiello L, Mattei M, Santodonato L, D’Agostino G, Muraro E, et al. Clinical and antitumor immune responses in relapsed/refractory follicular lymphoma patients after intranodal injections of IFNadendritic cells and rituximab: a phase I clinical trial. Clin Cancer Res. 2019;25(17):5231-41.

122. Garg AD, Coulie PG, Van den Eynde BJ, Agostinis P. Integrating nextgeneration dendritic cell vaccines into the current cancer immunotherapy landscape. Trends Immunol. 2017;38(8):577-93.

123. Anguille S, Smits EL, Bryant C, Van Acker HH, Goossens H, Lion E, et al. Dendritic cells as pharmacological tools for cancer immunotherapy. Pharmacol Rev. 2015;67(4):731

124. Wimmers F, Schreibelt G, Sköld AE, Figdor CG, De Vries IJM. Paradigm shift in dendritic cell-based immunotherapy: from in vitro generated monocyte-derived DCs to naturally circulating DC subsets. Front Immunol. 2014:5:165.

125. Schuurhuis DH, Verdijk P, Schreibelt G, Aarntzen EHJG, Scharenborg N, de Boer A, van de Rakt MWMM, Kerkhoff M, Gerritsen MJP, Eijckeler F, Bonenkamp JJ, Blokx W, van Krieken JH, Boerman OC, Oyen WJG, Punt CJA, Figdor CG, Adema GJ, de Vries IJM. In situ expression of tumor antigens by messenger RNA-electroporated dendritic cells in lymph nodes of melanoma patients. Cancer Res. 2009;69(7):2927-34

126. Bedrosian I, Mick R, Xu S, Nisenbaum H, Faries M, Zhang P, Cohen PA, Koski G, Czerniecki BJ. Intranodal administration of peptide-pulsed mature dendritic cell vaccines results in superior CD8+ T-cell function in melanoma patients. J Clin Oncol. 2003;21(20):3826-35.
127. Dohnal AM, Witt V, Hügel H, Holter W, Gadner H, Felzmann T. Phase study of tumor Ag-loaded IL-12 secreting semi-mature DC for the treatment of pediatric cancer. Cytotherapy. 2007;9(8):755-70.

128. Fong L, Brockstedt D, Benike C, Wu L, Engleman EG. Dendritic cells injected via different routes induce immunity in cancer patients. J Immunol. 2001;166(6):4254-9.

129. West E, Morgan R, Scott K, Merrick A, Lubenko A, Pawson D, et al. Clinical grade OK432-activated dendritic cells: in vitro characterization and tracking during intralymphatic delivery. J Immunother. 2009;32(1):66-78

130. Rodríguez-Ruiz ME, Perez-Gracia JL, Rodríguez I, Alfaro C, Oñate C, Pérez G, Gil-Bazo I, Benito A, Inogés S, de Cerio AL, Ponz-Sarvise M, Resano L, Berraondo P, Barbés B, Martin-Algarra S, Gurpide A, Sanmamed MF, de Andrea C, Salazar AM, Melero I. Combined immunotherapy encompassing intratumoral poly-ICLC, dendritic-cell vaccination and radiotherapy in advanced cancer patients. Ann Oncol. 2018;29(5):1312-9.

131. Morse MA, Deng Y, Coleman D, Hull S, Kitrell-Fisher E, Nair S, et al. A phase I study of active immunotherapy with carcinoembryonic antigen peptide (CAP-1)-pulsed, autologous human cultured dendritic cells in patients with metastatic malignancies expressing carcinoembryonic antigen. Clin Cancer Res. 1999;5(6):1331-8.

132. Barratt-Boyes SM, Watkins SC, Finn OJ. Migration of cultured chimpanzee dendritic cells following intravenous and subcutaneous injection. Adv Exp Med Biol. 1997;417:71-5.

133. Ando K, Fujita H, Hosoi A, Ma L, Wakatsuki M, Seino Kl, et al. Intravenous dendritic cell administration enhances suppression of lung metastasis induced by carbon-ion irradiation. J Radiat Res. 2017:58(4):446-55.

134. Gargett T, Abbas MN, Rolan P, Price JD, Gosling KM, Ferrante A, et al. Phase I trial of Lipovaxin-MM, a novel dendritic cell-targeted liposomal vaccine for malignant melanoma. Cancer Immunol Immunother CII. 2018:67(9):1461-72.

135. Gilliet M, Kleinhans M, Lantelme E, Schadendorf D, Burg G, Nestle FO. Intranodal injection of semimature monocyte-derived dendritic cells induces Thelper type 1 responses to protein neoantigen. Blood. 2003;102(1):36-42.

136. Castro JE, Melo-Cardenas J, Urquiza M, Barajas-Gamboa JS, Pakbaz RS Kipps TJ. Gene immunotherapy of chronic lymphocytic leukemia: a phase I study of intranodally injected adenovirus expressing a chimeric CD154 molecule. Can Res. 2012;72(12):2937-48.

137. Willekens B, Presas-Rodríguez S, Mansilla MJ, Derdelinckx J, Lee WP, Nijs $\mathrm{G}$, et al. Tolerogenic dendritic cell-based treatment for multiple sclerosis (MS): a harmonised study protocol for two phase I clinical trials comparing intradermal and intranodal cell administration. BMJ Open. 2019;9(9): e030309.

138. Morisaki T, Hikichi T, Onishi H, Morisaki T, Kubo M, Hirano T, et al. Intranodal administration of neoantigen peptide-loaded dendritic cell vaccine elicits epitope-specific T cell responses and clinical effects in a patient with chemorefractory ovarian cancer with malignant ascites. Immunol Invest. 2021:50(5):562-79.

139. Karthaus N, Torensma R, Tel J. Deciphering the message broadcast by tumor-infiltrating dendritic cells. Am J Pathol. 2012;181(3):733-42.

140. Tran Janco JM, Lamichhane P, Karyampudi L, Knutson KL. Tumorinfiltrating dendritic cells in cancer pathogenesis. J Immunol. 2015;194(7):2985-91.

141. Zhang Y, Mao Q, Xia Q, Cheng J, Huang Z, Li Y, et al. Noncoding RNAs link metabolic reprogramming to immune microenvironment in cancers. J Hematol Oncol. 2021;14(1):169.

142. Liu Y, Zhou X, Wang X. Targeting the tumor microenvironment in B-cell lymphoma: challenges and opportunities. J Hematol Oncol. 2021:14(1):125

143. Nahas MR, Stroopinsky D, Rosenblatt J, Cole L, Pyzer AR, Anastasiadou E, et al. Hypomethylating agent alters the immune microenvironment in acute myeloid leukaemia (AML) and enhances the immunogenicity of a dendritic cell/AML vaccine. Br J Haematol. 2019:185(4):679-90.

144. Kwon YR, Kim HJ, Sohn MJ, Lim JY, Park KS, Lee S, et al. Effects of decitabine on allogeneic immune reactions of donor lymphocyte infusion via activation of dendritic cells. Exp Hematol Oncol. 2020;9:22.

145. Almstedt M, Blagitko-Dorfs N, Duque-Afonso J, Karbach J, Pfeifer D,

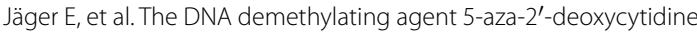


induces expression of NY-ESO-1 and other cancer/testis antigens in myeloid leukemia cells. Leuk Res. 2010;34(7):899-905.

146. Wong KK, Hassan R, Yaacob NS. Hypomethylating agents and immunotherapy: therapeutic synergism in acute myeloid leukemia and myelodysplastic syndromes. Front Oncol. 2021;11:624742.

147. Griffiths EA, Srivastava P, Matsuzaki J, Brumberger Z, Wang ES, Kocent $J$, et al. NY-ESO-1 vaccination in combination with decitabine induces antigen-specific T-lymphocyte responses in patients with myelodysplastic syndrome. Clin Cancer Res. 2018;24(5):1019-29.

148. Andersen $\mathrm{MH}$. The targeting of immunosuppressive mechanisms in hematological malignancies. Leukemia. 2014;28(9):1784-92.

149. Sengal A, Velazquez J, Hahne M, Burke TM, Abhyankar H, Reyes R, et al. Overcoming T-cell exhaustion in LCH: PD-1 blockade and targeted MAPK inhibition are synergistic in a mouse model of $\mathrm{LCH}$. Blood. 2021:137(13):1777-91.

150. Versteven M, Van den Bergh JMJ, Marcq E, Smits ELJ, Van Tendeloo VFI, Hobo W, et al. Dendritic cells and programmed death-1 blockade: a joint venture to combat cancer. Front Immunol. 2018;9:394.

151. Calmeiro J, Carrascal MA, Tavares AR, Ferreira DA, Gomes C, Cruz MT, et al. Pharmacological combination of nivolumab with dendritic cel vaccines in cancer immunotherapy: an overview. Pharmacol Res. 2021;164: 105309

152. Zhu S, Zhang T, Zheng L, Liu H, Song W, Liu D, et al. Combination strategies to maximize the benefits of cancer immunotherapy. J Hematol Oncol. 2021;14(1):156

153. Yi M, Niu M, Zhang J, Li S, Zhu S, Yan Y, et al. Combine and conquer: manganese synergizing anti-TGF- $\beta$ /PD-L1 bispecific antibody YM101 to overcome immunotherapy resistance in non-inflamed cancers. J Hematol Oncol. 2021;14(1):146.

154. Zhao Z, Zheng L, Chen W, Weng W, Song J, Ji J. Delivery strategies of cancer immunotherapy: recent advances and future perspectives. J Hematol Oncol. 2019;12(1):126.

155. Marin-Acevedo JA, Kimbrough EO, Lou Y. Next generation of immune checkpoint inhibitors and beyond. J Hematol Oncol. 2021;14(1):45.

156. Yi M, Zhang J, Li A, Niu M, Yan Y, Jiao Y, et al. The construction, expression, and enhanced anti-tumor activity of YM101: a bispecific antibody simultaneously targeting TGF- $\beta$ and PD-L1. J Hematol Oncol. 2021;14(1):27.

157. Pan C, Liu H, Robins E, Song W, Liu D, Li Z, et al. Next-generation immuno-oncology agents: current momentum shifts in cancer immunotherapy. J Hematol Oncol. 2020;13(1):29.

158. Iżykowska K, Rassek K, Korsak D, Przybylski GK. Novel targeted therapies of T cell lymphomas. J Hematol Oncol. 2020;13(1):176.

159. Tian Z, Liu M, Zhang Y, Wang X. Bispecific T cell engagers: an emerging therapy for management of hematologic malignancies. J Hematol Oncol. 2021;14(1):75.

160. Qian W, Zhao M, Wang R, Li H. Fibrinogen-like protein 1 (FGL1): the next immune checkpoint target. J Hematol Oncol. 2021;14(1):147.

161. Jiang Z, Sun H, Yu J, Tian W, Song Y. Targeting CD47 for cancer immunotherapy. J Hematol Oncol. 2021:14(1):180.

162. Stroopinsky D, Liegel J, Bhasin M, Cheloni G, Thomas B, Bhasin S, et al. Leukemia vaccine overcomes limitations of checkpoint blockade by evoking clonal $\mathrm{T}$ cell responses in a murine acute myeloid leukemia model. Haematologica. 2021;106(5):1330-42.

163. Lichtenegger FS, Krupka C, Haubner S, Köhnke T, Subklewe M. Recent developments in immunotherapy of acute myeloid leukemia. J Hematol Oncol. 2017;10(1):142.

164. Filin IY, Kitaeva KV, Rutland CS, Rizvanov AA, Solovyeva WV. Recent advances in experimental dendritic cell vaccines for cancer. Front Oncol. 2021;11:730824.

165. Lapenta C, Donati S, Spadaro F, Lattanzi L, Urbani F, Macchia I, et al. Lenalidomide improves the therapeutic effect of an interferon- $a$ dendritic cell-based lymphoma vaccine. Cancer Immunol Immunother CII. 2019;68(11):1791-804

166. Zhao W, Zhao G, Wang B. Revisiting GM-CSF as an adjuvant for therapeutic vaccines. Cell Mol Immunol. 2018;15(2):187-9.

167. Birge RB, Boeltz S, Kumar S, Carlson J, Wanderley J, Calianese D, et al. Phosphatidylserine is a global immunosuppressive signal in efferocytosis, infectious disease, and cancer. Cell Death Differ. 2016;23(6):962-78.
168. Bondanza A, Zimmermann VS, Rovere-Querini P, Turnay J, Dumitriu IE, Stach CM, et al. Inhibition of phosphatidylserine recognition heightens the immunogenicity of irradiated lymphoma cells in vivo. J Exp Med. 2004;200(9):1157-65.

169. van Beek JJ, Gorris MA, Sköld AE, Hatipoglu I, Van Acker HH, Smits EL, et al. Human blood myeloid and plasmacytoid dendritic cells cross activate each other and synergize in inducing NK cell cytotoxicity. Oncoimmunology. 2016;5(10): e1227902.

170. Van Acker HH, Beretta O, Anguille S, De Caluwé L, Papagna A, Van den Bergh JM, et al. Desirable cytolytic immune effector cell recruitment by interleukin-15 dendritic cells. Oncotarget. 2017;8(8):13652-65.

171. van Ee TJ, Van Acker HH, van Oorschot TG, Van Tendeloo VF, Smits EL, Bakdash G, et al. BDCA1+CD14+ immunosuppressive cells in cancer, a potential target? Vaccines. 2018;6(3):65.

172. Curti A, Trabanelli S, Onofri C, Aluigi M, Salvestrini V, Ocadlikova D, et al. Indoleamine 2,3-dioxygenase-expressing leukemic dendritic cells impair a leukemia-specific immune response by inducing potent $\mathrm{T}$ regulatory cells. Haematologica. 2010;95(12):2022-30.

173. Giannopoulos K. Targeting immune signaling checkpoints in acute myeloid leukemia. J Clin Med. 2019;8(2):236.

174. Anguille S, Smits EL, Lion E, van Tendeloo VF, Berneman ZN. Clinical use of dendritic cells for cancer therapy. Lancet Oncol. 2014;15(7):e257-67.

175. Kim H-R, Park J-S, Park J-H, Yasmin F, Kim C-H, Oh SK, et al. Cell-permeable transgelin-2 as a potent therapeutic for dendritic cell-based cancer immunotherapy. J Hematol Oncol. 2021;14(1):43.

\section{Publisher's Note}

Springer Nature remains neutral with regard to jurisdictional claims in published maps and institutional affiliations.

Ready to submit your research? Choose BMC and benefit from:

- fast, convenient online submission

- thorough peer review by experienced researchers in your field

- rapid publication on acceptance

- support for research data, including large and complex data types

- gold Open Access which fosters wider collaboration and increased citations

- maximum visibility for your research: over $100 \mathrm{M}$ website views per year

At BMC, research is always in progress.

Learn more biomedcentral.com/submissions 